\title{
Itinerario
}

http://journals.cambridge.org/lTI

Additional services for Itinerario:

Email alerts: $\underline{\text { Click here }}$

Subscriptions: Click here

Commercial reprints: $\underline{\text { Click here }}$

Terms of use : $\underline{\text { Click here }}$

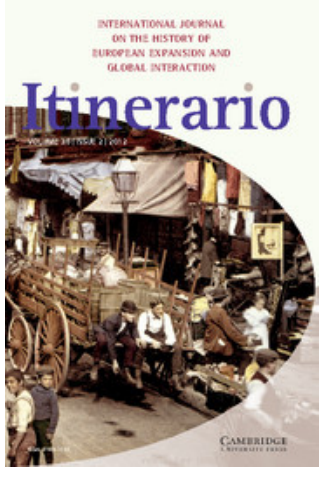

\section{Repositioning the Dutch in the Atlantic, 1680-1800}

Gert Oostindie and Jessica Vance Roitman

Itinerario / Volume 36 / Issue 02 / August 2012, pp 129 - 160

DOI: $10.1017 / S 0165115312000605$, Published online:

Link to this article: http://journals.cambridge.org/abstract_S0165115312000605

How to cite this article:

Gert Oostindie and Jessica Vance Roitman (2012). Repositioning the Dutch in the Atlantic, 1680-1800. Itinerario, 36, pp 129-160 doi:10.1017/S0165115312000605

Request Permissions : $\underline{\text { Click here }}$ 


\title{
Repositioning the Dutch in the Atlantic, 1680-1800
}

\author{
GERT OOSTINDIE \& JESSICA VANCE ROITMAN
}

After some decades of historical debate about the early modern Atlantic, it has become a truism that the Atlantic may better be understood as a world of connections rather than as a collection of isolated national sub-empires. Likewise, it is commonly accepted that the study of this interconnected Atlantic world should be interdisciplinary, going beyond traditional economic and political history to include the study of the circulation of people and cultures. This view was espoused and expanded upon in the issue of Itinerario on the nature of Atlantic history published thirteen years ago-the same issue in which Pieter Emmer and Wim Klooster famously asserted that there was no Dutch Atlantic empire. ${ }^{1}$ Since this controversial article appeared, there has been a resurgence of interest among scholars about the role of the Dutch in the Atlantic. With Atlantic history continuing to occupy a prominent place in Anglo-American university history departments, it seems high time to appraise the output of this resurgence of interest with an historiographical essay reviewing the major works and trends in the study of the Dutch in the Atlantic.

As part of this appraisal, it has become clear that despite the increase in publications on, and interest in, the Dutch in the Atlantic, there has been no comprehensive approach to the study of the Dutch in the Atlantic during the early modern period. Therefore, the goal of this article is two-fold. We consider the recent developments in the study of the Dutch in the Atlantic, particularly as foregrounded against the over-arching and constantly developing field of Atlantic history. But we also seek to redress this absence of a framework in which to investigate the multifaceted role of the Dutch in the Atlantic by suggesting an approach centred on what we term nodal points, that is the geographical spaces in which connections, intersections and interactions can best be analysed. We urge an approach that ance embraces the structure of the nation-state by looking at specifically Dutch nodal points, while recognising the limitations of focusing on any nation as a sole frame of reference in the imminently entangled Atlantic of the early modern period.

Thus, we will first discuss the state of the art in the historiography on the Dutch Atlantic, in particular its resurgence in the past decade, but also its tendency to stick to traditional subjects and approaches. The next section in the article proposes a typology of the Dutch Atlantic, with an emphasis on its connections to the wider Atlantic world. This typology is based, in part, on the recent output of scholarship 
that we review in the first section. We then go on to address the paradox that stalks all historians of the Atlantic: the desire to understand the Atlantic as an integrated whole over and against the logistical exigencies that seem to inexorably push research that focused on one "national" sub-empire. With developments in Atlantic history serving as a backdrop, we will then define our own position within the context of the existing approaches to the Dutch in the Atlantic. By way of a preliminary conclusion, we offer some hypotheses and questions regarding the defining characteristics of the "Dutch" Atlantic and its place in the Atlantic world, as seen through the lens of a cis-Atlantic approach centred in and on nodal points.

\section{The Historiography of the Dutch Atlantic: An Appraisal}

In the mid-1980s, at a time that few Dutch historians paid attention to their own Atlantic history, the American geographer D.W. Meinig emphasised the importance of the Dutch in the Atlantic. Meinig's four-volume The Shaping of America: A Geographical Perspective on 500 Years of History already employed what David Armitage would later describe as a large-scale cis-Atlantic approach. ${ }^{2}$ Meinig's work described interrelationships within vast regions of the Atlantic and then drew conclusions on the impact these broader linkages had on specific (smaller) regions. This method of analysing the Atlantic led Meinig to a refreshing focus on the successes of Dutch commerce in the Atlantic, rather than on colonisation per se. Instead of building a colonial empire, Meinig stressed, the Dutch became important agents in several Atlantic trading circuits such as the slave trade between West Africa and the Caribbean and the trade in tropical products between the Caribbean and Europe. ${ }^{3}$ Thus Meinig presented the Dutch Atlantic "empire" as a geographically fragmented network of strategic nodal points along critical trade routes. ${ }^{4}$

Directly and indirectly, Meinig's work seems to have led to a revisionist impulse amongst scholars of the Dutch in the Atlantic. Certainly, the 1990s and early 2000s saw a marked increase in publications about the Dutch in Atlantic. ${ }^{5}$ The Dutch Research Council (NWO) funding of a project on "Dutch Atlantic Connections" between 2008 and 2012 results, in part, from this impulse, and from the questions raised by the contributors to Riches from Atlantic Commerce: Dutch Transatlantic Trade and Shipping, 1585-1817, a volume of essays published in 2003. This collection was the product of a symposium held on "Dutch Atlantic Shipping, 1600-1800" at Leiden University in 1996. ${ }^{6}$ All were concerned, ultimately, with revisiting, revising, and reassessing the traditional (Dutch) historiography about the value of the Atlantic to the Dutch both economically and, to a much lesser extent, socially and culturally. And this re-examination of the history of the Dutch in the Atlantic seems to have borne fruit. Not only is far more research being done into all aspects of the Dutch in the Atlantic, but much of what was justifiably decried in 2003 as an "academic imbalance" in favour of the study of the Dutch East Indies is being redressed. ${ }^{7}$ Dutch Atlantic history is no longer the purview of a few scholars engaged in a small niche of the Dutch past, but is a growing and dynamic field of interest in both national and international academic institutions.

Looking back on the developments of the historiography of the Dutch Atlantic, several conclusions are clear. First, until relatively recently, the entire subject was significantly under-studied, and what research was done focused either on the 
Dutch West India Company (WIC) or on individual colonies in the Atlantic. Suriname is the best-researched single colony, followed by New Netherland, Curaçao, Dutch Brazil, Elmina, and St. Eustatius, with the nearly forgotten colonies of Berbice, Demerara, and Essequibo lagging far behind in terms of scholarly interest. ${ }^{8}$ But few of these studies on individual colonies or settlements take a broader Atlantic perspective. For example, in studies of Suriname, slavery and the plantation economy are the most extensively researched subjects - with analyses of trade and finance almost exclusively focusing on relations between metropolis and colony, with little or nothing done to contextualise this colony in the greater Atlantic world. ${ }^{9}$

Indeed most of these studies all but ignore the larger Atlantic context of these colonies. The Atlantic may have been overlooked or viewed as a somewhat embarrassing interlude in an otherwise more successful colonial past, due at least partly to the financial failures of the WIC, especially when compared to the Dutch East India Company (VOC). ${ }^{10}$ But this snubbing of the Atlantic could just as well stem from the relative lack of importance of the West Indies in the nineteenth century and the concomitant significance of the East Indies during this vital period for the foundation of Dutch history writing. ${ }^{11}$ Certainly, there have been Dutch scholars who have focused on the Dutch Atlantic, but with the possible exception of the Dutch slave trade which is, by definition, a subject that has to be at least somewhat contextualised within an Atlantic perspective, most of these scholars were firmly entrenched in the field of colonial history and viewed warfare, trade, and colonisation within a specifically or predominantly Dutch framework.

Moreover, within this colonial history perspective the vast majority of works dealing with the Dutch in the Atlantic focus primarily on trade. For instance, one of the first books to appear after Meinig's Shaping of America was Jonathan Israel's Dutch Primacy in World Trade in 1989. ${ }^{12}$ Though not intended to situate itself within the colonial history genre, among other controversial theses was Israel's assertion that the Atlantic had been of great importance for the economic development of the Dutch Republic. In contrast to prevailing opinion which emphasised the limited number of Dutch colonial possessions in the West and their minor economic importance to trade and industry in the Dutch Republic, Israel focused on the role of individuals and private concerns rather than on the WIC itself, and showed how, in the first half of the eighteenth century, these private undertakings had been quite successful. ${ }^{13}$

A year later, Johannes Postma published The Dutch in the Atlantic Slave Trade, 1600-1815. Clearly focused on commercial issues - in this case the slave tradethe book also placed the history of the Dutch in the Atlantic firmly in the prevailing currents of Anglo-Saxon Atlantic historiography. ${ }^{14}$ Likewise, in 1992, Pieter Emmer and Ernst van den Boogaart published a Spanish-language volume entitled, La expansión holandesa en el Atlántico which sought to place Dutch expansion in an Atlantic perspective. ${ }^{15}$ Emmer continued engaging the largely Anglo-Saxon debates on slavery and on Dutch trade in the Atlantic in his collection of essays The Dutch in the Atlantic Economy, 1580-1880, published in $1998 .{ }^{16}$ On the first page, he asks why the history of the Dutch expansion in the Atlantic has been neglected and concluded, in part, that this "negligence in studying the Atlantic past is [because] the Dutch were not very important in that part of the world," and goes on to write that it "seemed more attractive to concentrate on the history of the Dutch in Asia." 17 
Emmer's questioning of the importance of the Atlantic for the Dutch Republic continued in The Dutch Slave Trade, 1500-1850, published in 2006, in which he argues that the Dutch had a relatively insignificant share in the Atlantic slave trade-averaging 5 to 6 per cent of the total. ${ }^{18}$ However, he contends that the Dutch did have a significant role in the development of the trade in the first half of the seventeenth century, not only through supplying their short-lived Brazilian colony with slaves, but, perhaps more importantly, by stimulating the cultivation of sugarwith the consequent demand for slaves this entailed-in the French and English Caribbean. The Dutch then turned to Spanish America, transporting around 100,000 slaves to this region by $1730 .^{19}$

Working in the same economically-focused vein as Emmer, Jan de Vries and Ad van der Woude wondered in their book The First Modern Economy: Success, Failure, and Perseverance of the Dutch Economy, 1500-1815, published in 1997, if, apropos of the loss of Dutch Brazil, "the Dutch were too rational to be good imperialists." ${ }^{20}$ While emphasising the importance of the Republic's Atlantic trade in comparison to its Asian trade, de Vries and van der Woude's overall analysis is that "The 200 year history of the Dutch Atlantic economy is one of repeated cycles of hope, frustration, and failure." ${ }^{21}$ Some of the hopeful moments in the Dutch Atlantic economy were the innovations provided by the commercial system, which made the frustrations even greater when these were marginalised by the mercantilist endeavours of France and Britain. ${ }^{22}$ There was also hope to be had from the recreation of colonial production centres, when the value of Dutch plantation exports grew at an average rate of 2.8 per cent per year, making it "easily the most dynamic sector of Dutch trade in the eighteenth century."23

Eight years after this seminal book, Jan de Vries' essay, "The Dutch Atlantic Economies," reiterates that the Dutch presence in the Atlantic world "has long appeared both unimpressive and unimportant". ${ }^{24}$ Summarising many of the arguments he and van der Woude made in The First World Economy, he states that the Netherlands' engagement with the Atlantic was "filled with frustration and disappointment, never resulting in a territorial, political or cultural presence that answered to the grand visions of successive generations of advocates." ${ }^{25}$ Nevertheless, he goes on to state that "historians have long been inclined to depreciate too much the importance of the New World to the Dutch Republic". ${ }^{26}$ Viewing Dutch involvement in the Atlantic through the lens of merchants and investors in the seventeenth and eighteenth centuries, de Vries emphasises how the Atlantic was perceived as an important zone of commercial activity, in which the failures of colonisation and attendant assertion of political power were not particularly lamented. ${ }^{27}$ In fact, de Vries shows that by the 1770s the Dutch imported more from the West Indies than from Asia. De Vries expands upon this analysis in an article from 2010 in which he shows that in the 1770s, imports from the Western Hemisphere accounted for nearly one third of total imports for the British, French, and Dutch, as opposed to about 11 per cent for Asia, and this is without including other European countries, especially Spain and Portugal. At the same time, de Vries' figures also indicate that the importance of Atlantic trade was relatively more important to the British and French than it was to the Dutch. ${ }^{28}$

De Vries' economic analysis is further bolstered by Clé Lesger's data on the taxes paid by ships coming into Amsterdam's harbour, which shows the growth in ship- 
ping from the New World in the last half of the eighteenth century. ${ }^{29}$ Recently, Henk den Heijer has argued that about 70 per cent of Dutch activities in the Atlantic were beyond the purview of the WIC. Two examples he names are sugar and tobacco, commodities with which the WIC had nothing to do. ${ }^{30}$ Along these lines, Wim Klooster's dissertation, published in 1998, demonstrated the importance of the Atlantic for the Dutch Republic by showing the importance of the Caribbean trade, most of which was not officially registered and is therefore difficult to quantify. ${ }^{31}$

Most of these works have reshaped the traditional (Dutch) historiography about the value of the Atlantic to the Dutch economy, and even some authors such as Klooster and de Vries who were initially somewhat dismissive of the importance of the Atlantic for the Dutch have since modified their views. Yet all of these scholars still tend to structure their research within a predominantly Dutch framework. With the exception of Klooster's Illicit Riches, there are few publications that consider the Dutch Atlantic in light of entanglements with other empires, and works that incorporate the motives, perspectives, and strategies of other empires and their residents. $^{32}$ This is an approach in which studies of the colonial period in North America excel. Joyce Goodfriend has been tireless in calling for the inclusion of the Dutch in the narrative of British North America, work that scholars such as Jaap Jacobs have aided. ${ }^{33}$ Both Claudia Schnurmann and April Lee Hatfield demonstrate the importance of communities of Dutch settlers for the development of Virginia and Boston, as well as New York. ${ }^{34}$ And they look not only at the economic importance of these Dutch settlers for the British Atlantic, but also at the development of what Schnurmann dubs a "supra-national" identity based on regional interests and economic, social, and cultural entanglements. ${ }^{35}$

In conclusion, there has been a serious effort at catching up over the past two decades, and yet the historiography of the Dutch Atlantic and its connections to the wider Atlantic is clearly lagging behind, not only in quantity, but equally when it comes to multidisciplinary and innovative approaches. For example, the historiography of the Dutch in the Atlantic described above is overwhelmingly economic in its orientation. We have said nothing of works of social or cultural history, not because we are remiss but because there are simply so few. Other than tightly focused studies of the cultural and social life of individual colonies, there is next to nothing written on the Dutch in the Atlantic that addresses broader themes such as the transfer of ideas, political integration, and the social and cultural impact of the Atlantic on the Dutch Republic. The one looming exception to this statement is the work of Benjamin Schmidt, who studies the influence of ideas of the Atlantic on the Dutch Republic. ${ }^{36}$ In addition, Klooster has written about the development of unique colonial identities within the context of "centre and periphery." ${ }^{37}$ Thus, one understands why Laura Cruz characterised Dutch historiography, in general, and Dutch Atlantic historiography in particular, as conservative. ${ }^{38}$

\section{The "Dutch" Atlantic, 1680-1800: Periodisation and Characteristics}

So what does this historiography allow us to say about the Dutch in the Atlantic? What are the defining characteristics of the Dutch Atlantic and its wider connections 
between 1680 and 1800? What developments were crucial to the formation of the Dutch Atlantic, and what periodisation is most appropriate?

\section{Basic Assumptions}

One of the basic tenets of Atlantic history is that the study of this vast space should not be reduced to national categories, but should, instead, supersede them by crossing and combining borders of all kinds. Linkages between the various national empires characterise the early modern Atlantic world so much that it is well-nigh impossible to detect where one empire begins and the other ends. We suggest that the "Dutch Atlantic" is the most radical case for this statement. There was no such thing as a homogeneous Dutch empire in the Atlantic, and conversely, several Dutch colonies were disproportionally active as hubs between various sub-empires, and Dutch merchants and financiers were remarkably active throughout the wider Atlantic.

What about the "Dutch" character of the Dutch Atlantic? In a comparative perspective, the character of the various Dutch colonies and settlements was exceptionally heterogeneous. But does this mean that the overseas territories were unreflective of metropolitan culture? Not necessarily. For one thing, there were typical metropolitan transfers to the various Atlantic settlements, such as in arrangements regarding governance and jurisprudence as well as, among the white settlers, the dominance of the Dutch Reformed Church, a tolerance for other religious groups, and the (not necessarily majority) usage of the Dutch language. We may also argue that the lack of uniformity in policing the various colonies and the resulting contrasts between them reflects a similar lack of centralisation within the Dutch Republic itself, just as the low level of mercantilism within the Dutch Atlantic reflects Dutch governance at home.

We will briefly focus on Dutch national politics; geopolitics; economy; demography and ethnicity; and cultural transfers and the circulation of ideas in order to flesh out and systematise our arguments. First, though, we will explain our demarcations of the period under study. We have opted for geopolitical markers to delineate our chronology. The year 1680 marks the beginning of relatively stable period. By then, the Dutch had opted for settling in Elmina rather than further South in the Luanda region, had lost Brazil and New Netherland, and had conquered Suriname, Berbice, Demerara, and Essequibo, as well as the six Antillean islands. Some brief disruptions aside, this sub-empire would remain intact until the start of the Napoleonic Wars at the turn of the nineteenth century. By then the WIC had already gone bankrupt (1792). What happened afterwards-events such as the French occupation of the Netherlands and the British seizure of the Dutch colonies, the abolition of the slave trade, and so forth-while interesting and not unimportant, are not the concern of this article and, therefore, will not be explored.

\section{National Politics, Governance Arrangements, Geopolitics}

For the entire period under study, government in the Dutch Republic was based on provincial assemblies and ruling municipal councils. Provinces had a great deal of power, with the province of Holland and, particularly, the city of Amsterdam striving for (and often attaining) national hegemony. Thus, the political structure of the Dutch Republic was much less centralised than that of other European states with 
a direct stake in the Atlantic. Moreover, the Netherlands was not a monarchy, in contrast to other nations engaging in Atlantic endeavours. This meant that within the Republic a complex set of actors had an interest in, and rights to dictate policy over, particular colonies or even over the entire Dutch Atlantic. For instance, the States-General transferred part, but certainly not all, of its power to the WIC, a company without a monopoly and divided within itself along Dutch provincial and municipal lines. And of course this was a company competing with and sharing overseas engagement with different sets of ad hoc institutions, merchant houses and such.

Governance arrangements within the various colonies mirrored this state of affairs in the metropole. Rather than one uniform model for colonial rule, there was a rather unstructured set of divergent governance models for what may only very loosely be defined as "the Dutch Atlantic." We do see changes over time, though. The Republic first attempted to farm out settlement in the colonies partly through the WIC, partly through mixed semi-state, and also via strictly private, initiatives. The latter option, the so-called patroons-parcels of land grants-were issued to applicants with the understanding that they would ensure its colonisation with at least fifty colonists within three years' time. The applicants had administrative and judicial powers over their land. At later stages, these patroonschappen were converted to mixed chartered companies, but these too retained a considerable degree of local autonomy. ${ }^{39}$ These sorts of settlement schemes met with limited success and died out fairly quickly. Their legacy endured, however, in the form of diverse and often divergent governance structures in the colonies. By the 1730s, the WIC had lost its commercial monopoly but remained the principal governmental institution. Within the WIC, conflicts between Holland, particularly Amsterdam, and Zeeland continued to have a disruptive effect on colonial rule, with Zeeland increasingly relegated to a secondary role, but fighting tooth and nail against this relegation until the late eighteenth century.

In the colonies, the WIC acted as the sole government in the Antilles, but had to share this role elsewhere. In 1682, Zeeland was forced to relinquish Suriname as a provincial asset, and four years later governance was entrusted to a "Sociëteit van Suriname" in which the Amsterdam-dominated WIC and the city of Amsterdam would be preeminent throughout the period under analysis. Likewise, after a start as a patroonschap belonging to a colonist from Zeeland, control of Berbice was transferred in 1720 to a "Sociëteit van Berbice" established by Amsterdam merchants; in both cases, the WIC had delegated much of its authority. Essequibo was run solely by private parties up to 1670 , and, thereafter, by the Zeeland chamber of the WIC. After the mid-eighteenth century, conflicts over trading and investment rights divided the Zeeland oligarchy and Amsterdam merchants. In general, throughout this entire period, local government enjoyed a good deal of practical sovereignty (reluctantly) delegated by the WIC in matters such as the administration of justice, the making of treaties, and the maintenance of military forces. ${ }^{40}$

As for geopolitics, the loss of two of the first Dutch endeavours in the Atlantic (Dutch Brazil and New Netherland) testifies to the short span of the Republic's leading role in Europe and, by extension, the Atlantic. By the late seventeenth century, the Dutch political and military edge among the Western European states had evaporated, and the Republic's expansionist ambitions dissipated. Dutch shipping 
capacity remained relatively high, but military strength was limited, and so was the Dutch Atlantic sub-empire. It was not really a territory to boast of, whether in comparison to the realm controlled by the VOC in Asia or to the Iberian, British or French presence in the Atlantic.

And yet this lack of empire, in the commonly understood sense of the word, and inadequate military resources did not stand in the way of successful intra-Atlantic, cross-imperial trade. For one thing, it made the Dutch more flexible in their economic policies while their competitors still clung at least officially to mercantilism. ${ }^{41}$ The neutral position of the Republic in the eighteenth century was even favourable to Dutch trade in the Caribbean. Islands like Curaçao and St. Eustatius emerged as free-trade hubs and were frequently used by the Caribbean colonies of competing and even warring parties for the import and export of commodities and tropical products. St. Eustatius was even lauded by political economists Adam Smith and Thomas François Raynal for its prosperity stemming from a free-market approach. ${ }^{42}$ But, as would become clear many times throughout the period under study, the lack of military power made the Dutch colonies and their Atlantic trade vulnerable, particularly to the British and the French.

\section{The Dutch Atlantic Economy}

The Dutch Republic had a significant domestic demand coupled with a transit market for Atlantic produce. There was, therefore, room for trade in staple products produced both in the Dutch as well as in the British and French Atlantic colonies. This, in turn, stimulated the emergence of a capital market and financial institutions covering the entire Atlantic. Of course, this was not exclusively an Atlantic affair, given the heavy Dutch involvement in intra-European and Asian trade and finance even prior to the beginning of their Atlantic endeavours. And, certainly, this was not an economy steered exclusively by the WIC. Whereas the VOC had a monopoly in governance as well as trade in the East Indies, the WIC had to abandon such aspirations early on. In 1730, the WIC relinquished its last remaining monopoly-the slave trade-and the company ceased to engage in slave trading itself by the end of that decade..$^{43}$ Extracting taxes on private trade would become its major economic activity. Nonetheless, while the WIC would continue to be an economic failure, we see a pronounced increase in the importance of the Atlantic to the Dutch economy as a whole.

Until the mid-seventeenth century, the Dutch role in the Atlantic was based largely on the production of its colonial possessions. New Netherlands, for example, provided the Republic with beaver and otter pelts, Elmina and Angola with gold, ivory and the income earned by selling enslaved Africans in the Americas, and Brazil with sugar and dyewood. But paradoxically, a new reality came into being after the collapse of the early Dutch Atlantic empire in the middle part of the seventeenth century. While the Dutch Republic was at the height of its economic and maritime power, it was downgraded to a minor player in the Atlantic if we judge its position based on the significance of the Republic's own colonies. But, as the essays in Riches from Atlantic Commerce demonstrates, despite this seemingly poor showing, the economic role of the Republic and its colonies in the Atlantic suffered less than might be expected. The next phase was one of geopolitical contraction but economic expansion. 
In contrast to traditional views on the subject, the Dutch Atlantic economy in the early modern period was not limited to the African slave trade and the development of slavery-based plantation colonies in Brazil and, later, the Guyanas. Dutch shipping and trade in the entire Atlantic was of far more importance than has been routinely assumed, precisely because of Dutch activities outside of the Republic's own colonies. Dutch Atlantic trading demonstrated structural growth throughout much of the period under consideration. In spite of the loss of their Atlantic "empire", the Dutch were able to create a profitable niche market based on their trade in the Americas. According to Klooster, in the mid-eighteenth century the Dutch share of the total trade in the Atlantic amounted to a not insignificant 8.5 per cent. ${ }^{44}$

Upon closer consideration, this percentage posited by Klooster should be even higher, as his estimate does not include the production of the plantation colonies of Berbice, Essequibo, and Demerara, nor does it include the indirect imports of tobacco, sugar and other tropical products via British and French port cities. In general, it should be emphasised that, while the Dutch colonies in the West may have been small and few, Dutch and Dutch Caribbean merchants operating there succeeded in rerouting part of the production of the surrounding Spanish, French, and English colonies. The estimated value of Dutch imports from and via its own colonies of Curaçao, St. Eustatius and Suriname rose from 4.3 million guilders at the beginning of the eighteenth century to 18.5 million guilders at the end. ${ }^{45}$ Once we include the trade figures from North America, growth is even more spectacular. One caveat should be made, however. Though we now know that Dutch Atlantic trade was more significant than heretofore assumed, it is not evident that the contribution of the Atlantic to the Dutch economy and its growth in the eighteenth century was remarkable in comparison to the domestic, European or Asian trades. It is not even certain that the Atlantic trade was actually on par with the significance of the Atlantic to the economies of other European powers.

Nevertheless, we have drawn some preliminary conclusions based upon the calculations on Dutch Atlantic trade offered by Jan de Vries, Wim Klooster and Victor Enthoven. ${ }^{46}$ Over time, these historians have all corrected their trade figures upwards. These upwards corrections are, to a large extent, based on having broadened the definition of what constituted "Dutch Atlantic trade". For instance, the initial estimates of Klooster only pertained to shipping between the Republic on the one hand, and Curaçao, St. Eustatius and Suriname on the other. The most recent estimates also include Berbice, Demerara, and Essequibo, as well as West Africa (Elmina). Meanwhile, Enthoven, in particular, also makes a strong point for including direct trade relations between the Dutch Republic and the North American colonies. $^{47}$

While there is room for some scepticism regarding the estimates, as all of these three scholars readily admit, all figures point to a strong growth in the value of Dutch Atlantic trading in the eighteenth century. According to de Vries, the annual value of Atlantic imports into the Republic stood at some 4.5 million guilders in the mid-seventeenth century, then dropped, but rose again and quadrupled between 1700 and 1780 , from an annual 4.3 to 22.4 million guilders. Enthoven produces a much higher figure for ca. 1780-over 30 million-including imports from nonDutch territories in the Americas. This would only strengthen the case for vibrant growth throughout most of the eighteenth century. ${ }^{48}$ 
A comparison to the value of imports into the Republic from Asia provides remarkable results. De Vries calculates that initial values of Asian imports were far above Dutch Atlantic imports: some 8 million guilders in the 1640s, gradually rising to some 20 million in the period 1750-80. The contrast is clear: Asian import growth was much lower, and, in the 1770s, West Indian imports surpassed Asian imports. Not surprisingly, Enthoven's figures suggest an even greater discrepancy. He copies de Vries' estimate of the value of Asian imports c. 1780 at 20 million guilders in comparison with 30 million for Atlantic imports. He suggests that the total trade turnover (including re-exports of colonial produce and Dutch exports) was 37.9 million guilders for the Dutch Asian trade which was set over and against an astounding 70 million for Dutch Atlantic trade. ${ }^{49}$

On the basis of this research we may safely conclude that this growth eventually made the Atlantic as important to the Republic as the Dutch Asian orbit, and, perhaps, even more significant. Unlike Asian imports, the tropical products from the Atlantic provided primary materials for Dutch industry and, hence, had significant spin-off effects for the economy. For instance, the Republic's European trade included a significant volume of transhipped French Caribbean sugar destined for Dutch refineries. All of which leads to a rectification of the established opinion that, for the Dutch Republic, the Atlantic was always of secondary importance in comparison with Asia. But this correction still does not help us answer two other comparative questions.

First, was the growth of Dutch Atlantic trade remarkable vis-à-vis the other Atlantic players? The answer is simple: no. The Dutch were minor players in the Atlantic. Klooster estimates that the Dutch share of the trade in American products was 5 per cent in the 1720 s and 1730 s and 8.5 per cent in the 1740 s and 1750 s. This proportion would rise if we were to include trade with the other Guianas and North America. Yet even if these additional trade figures were included, the Dutch still would not have been a player in the same league as Portugal, England or France, much less of Spain. De Vries compares the value of Atlantic imports into

Geographical structure of imports to Britain, France, and the Dutch Republic in the 1770s

\begin{tabular}{llll}
\hline & Britain & France & Netherlands \\
\hline Source of imports & $1772-73(\%)$ & $1772-76(\%)$ & $1770-79(\%)$ \\
\hline Europe & 45 & 53 & 71 \\
Western Hemisphere & 38 & 42 & 15 \\
Asia & 16 & 5 & 14 \\
Total value (in millions) & $£ 13.6$ & l.t. 369.6 & $f 147.4$ \\
\hline
\end{tabular}

Total value of imports to Britain, France, and the Dutch Republic in the 1770 s (millions of guilders)

\begin{tabular}{lrrrll}
\hline Source of imports & Britain & France & Netherlands & Total & \% of total imports \\
\hline Western & $f 57.4$ & $f 71.9$ & $f 22.4$ & $f 151.7$ & $f 32.3$ \\
Hemisphere & & & & & \\
Asia & 24.2 & 8.6 & 20.0 & 52.8 & 11.2 \\
Total & 151.1 & 171.1 & 147.4 & & \\
\hline
\end{tabular}

Source: Jan de Vries, "The limits of globalization in the early modern world," 729.

Note: Exchange rates: one guilder (or florin $(f))=11.11$ pounds sterling and 2.16 livres tournois (l.t). 
Britain, France, and the Dutch Republic in the 1770s, and demonstrates that the Dutch were a minor player in comparison to the British and the French. Of course, per capita Dutch involvement was more or less comparable to that of the British or French. But that obviously does not change the overall conclusion that the Republic was a minor player; it merely underlines the fact that that Republic itself was a relatively small nation. When we evaluate the figures based on the total imports for each of these nations, the results are noteworthy. Only in the Dutch case are the Asian and Atlantic trades of comparable magnitude. But both colonial trades were dwarfed by European imports.

All of this reminds us that we should be cautious in our revisionism. Certainly, an inaccurate perspective on the (lack of) importance of the Atlantic trade for the Dutch Republic emerged in the nineteenth and twentieth centuries when the fruits of colonialism were almost uniformly equated with the wealth created in the Dutch East Indies. Early modern Dutch Atlantic trade was, indeed, more important than has long been acknowledged, but, even so, its importance to the Republic should not be exaggerated. So a conservative revision of the historiography is the most realistic outcome of the latest figures which we have enumerated above. But these figures in no way tell the entire story when it comes to the importance of Dutch connections within the Atlantic. After all, trade from the Dutch Guianas, Curaçao and St. Eustatius with the North American colonies, as well as with other Caribbean islands, is not included in the above figures-and this trade involved not simply the circulation of commodities, but equally of people and ideas. The importance of this sort of circulation is nearly impossible to quantify, but is no less significant for this lack of quantification.

\section{Demography and Ethnicity}

In the first century after the Spanish conquista, indigenous populations in much of what would become the Dutch Atlantic had been decimated or pushed to the periphery by immigrants from Africa and Europe. ${ }^{50}$ With the exception of West African Elmina, the Dutch colonies in the Atlantic were mainly populated by immigrants, the great majority of whom were enslaved Africans and their descendants, and only a minority Europeans. Citizens from the prosperous Republic were not eager emigrants, and a considerable share of the European population in Dutch colonies, whether transients or settlers, originated from outside the Republic. Moreover, throughout the seventeenth and eighteenth centuries, the share of the total European population in the Dutch colonies remained comparatively small, the only exception being the Cape Colony, the extreme western point of the Republic's VOC orbit. After the 1660 s, immigration was mainly to the Caribbean colonies, with just a trickle to Elmina and larger numbers to North America, which was no longer a Dutch-controlled territory.

It is extremely difficult to calculate the number of Atlantic emigrants coming from or travelling via the Republic. This difficulty stems not only from missing or elusive figures, but also from what definitions we employ. For example, do we count only the number of people who crossed the Atlantic with the intention of settling, or do we include those who intended to settle for a limited period? Or should we include all passengers and crews on all ships leaving the Republic for either Elmina or the 
Americas? And do we only count inhabitants of the Republic, or do we add anybody embarking on a Dutch ship?

David Eltis, using calculations made by Jan Lucassen, arrives at a very conservative estimate of 20,000 migrants between 1600 and 1760, only 4 per cent of the approximately half a million migrants that Asia did. At the other extreme, Enthoven has arrived at a staggering number of $1,872,000$ people leaving the Republic for Atlantic destinations between 1600 and 1800, and 1,205,500 returning, meaning that, by his estimates, 700,000 "migrants" either settled in the Atlantic territories or died along the way. However, as Gijs Kruijtzer argues, this figure is inflated because it includes ships' crews and military men (hence one sailor or soldier crossing the Atlantic five times will count as five individuals). Moreover, Enthoven includes large contingents of non-Dutch emigrants transhipped by Dutch ships, including the approximately 100,000 Germans and Scandinavians who went to North America and later became known as the "Pennsylvania Dutch." 51

It seems safe to assume that the number of Dutch citizens crossing the Atlantic to settle elsewhere was modest, certainly in comparison to those settling in the VOC orbit, but also in comparison to the European population in other parts of the Atlantic. Around 1735, some 5,000 Europeans were living in all the Dutch Atlantic colonies taken together, in 1750 perhaps around 8,500, and by about 1800 just over 16,000. These figures do not include Dutch settlers and their offspring in nonDutch territories, particularly in North America, where their number increased considerably, possibly from just over 8,500 in 1700 to over 100,000 in the late eighteenth century. ${ }^{52}$ There is no doubt that Dutch Atlantic population growth was more substantial than in the Republic itself, where the total population increased at a very low rate, from just below $1,900,000$ around 1650 , to just over that figure in 1750 , and to $2,100,000$ by about $1800 .^{53}$

As was the case with Dutch involvement in Atlantic trade, figures for Dutch migration and settlement indicate that the Republic was an active, empire-crossing, but nonetheless numerically modest player in the wider Atlantic. Over one million Europeans settled in British America between 1600 and 1800, three quarters of these in North America. The total white population of British America increased roughly from 110,000 in 1660 to 320,000 in 1710 , and then grew again to $1,325,000$ in 1760 , before declining dramatically to approximately 465,000 around 1800 due to the loss of the thirteen North American colonies which became the United States of America. ${ }^{54}$ Estimates for French Atlantic migration up to 1800 vary from 100,000 to 300,000 . Around 1730, the total European population in the Americas may have been 73,000 , a figure that increased significantly in the next decades-St. Domingue alone grew from 10,400 in 1730 to 31,600 in $1780 .{ }^{55}$ Eltis' calculations for European migration to the Atlantic between 1500 and 1760 indicate that Britain, Spain and Portugal, respectively, were the three most important nations of origin, followed distantly by France and, lagging even further behind, the Dutch Republic. ${ }^{56}$

Proportions and segmentation between immigrant populations varied widely within the Americas. The European element in the Iberian colonies was stronger than elsewhere, as was the share of the mestizo and Eurafrican population. In the typical plantation societies of other nations, the European element was small, usually ranging between 5 and 10 per cent. This applied to the Dutch plantation 
colonies in the Guianas as well, but less so for the trade colonies of Curaçao and St. Eustatius, where the European and mixed segments taken together formed a significant part of the total population. This, of course, had profound consequences for patterns of creolisation within the Dutch Atlantic orbit.

The very concept of "Dutch" is problematic in reference to those Dutch who were peopling the Atlantic world. As applied to the European inhabitants of settlements, plantation colonies, and trade factories throughout the Atlantic the term "Dutch" could refer to people who were born in these regions, who had come there as migrants, or who were the descendants of immigrants from the Dutch Republic itself. In practice almost any white citizen living in the Dutch colonies and/or working in the Dutch Atlantic trading companies was considered Dutch, despite hailing from another part of Europe and, perhaps, being unable to speak Dutch at all. Posthoc identification is made more complicated by the fact that the English called anyone who was not French or Spanish "Dutch" because they were all "Deutsch" or, in some way, Germanic. ${ }^{57}$

For the Dutch Republic itself, unlike its other European competitors, economic development was highly dependent on immigration, and so was the human capital employed in overseas ventures. Flemish and Sephardic immigrants were key players in the early phases of Dutch Atlantic expansion, while migrants from other parts of Europe, especially the German states and Scandinavia, were crucial in Dutch military campaigns and as sailors. No other European power deployed so many foreigners as part of their imperial venture, whether as soldiers, sailors or administrators. ${ }^{58}$ In the Caribbean, Dutch ships' crews were increasingly mixed, consisting of European, free coloured and enslaved African sailors. ${ }^{59}$

Throughout the Dutch colonial orbit, Europeans born outside of the Republic were a strong minority or even a majority in the total white segment of the population. ${ }^{60}$ And the Dutch case is not entirely exceptional. The heterogeneity of European populations is vastly underestimated in the study of empires, in general. Looking back in history through the lens of the nation-state, historians tend to project an unduly unified view of a group of people overseas. Take, for example, the only European state that, according to Klooster and Emmer, could be viewed as actually having an Atlantic empire-the British. Even this empire was created, in part, by Scots and Irish (both subject peoples in English eyes and their own), as well as Jews and even a fair number of Dutch. ${ }^{61}$ The Spanish and Portuguese empires were partially peopled by the so-called New Christians and a whole panoply of other Europeans, and major financing for the Iberian overseas enterprises came from these New Christians, as well as the Genoese. As historian Tamar Hertzog, shows, it was not just Jews and Genoese, but a whole host of groups who populated the (Spanish) Americas. ${ }^{62}$

That being said, it is likely that the "Dutch" were more heterogeneous in their Atlantic endeavours than were other European states. This is not surprising. A considerable part of the population of the Republic itself was of recent immigrant stock, and its strong economic growth in the early phase of colonisation implied a demand for external migratory labour, mostly from Scandinavia, the German states and the north of France. ${ }^{63}$ This is not to say there were no "real" Dutch settlers. In the seventeenth century, for example, hundreds of emigrants from Zeeland settled on the Dutch Windward Islands of Saba, St. Eustatius and St. Martin. These 
remained small-scale settlements, however, and quickly lost their Dutch character-by the early eighteenth century Dutch was already a disappearing minority language. ${ }^{64}$

In conclusion, then, it is even more problematic to think of the Dutch colonies in the Atlantic as extensions of the metropolis than it is in the case of the other European empires. This has a host of obvious implications for the study of Dutch Atlantic cultures and processes of creolisation. But it should alert us again to the importance of minority ethnicities and non-Dutch actors in the building of networks within the Dutch Atlantic and beyond.

\section{Culture and Ideas}

From the above it stands to reason that there was considerable ethnic and cultural diversity within the Dutch Atlantic. To give but one example, the dominant language in Suriname was an English-based Creole (Sranan), in Curaçao a Spanish- and Portuguese-based Creole (Papiamentu), and in St. Eustatius a probably creolised version of English. Only in Berbice and the Danish Virgin Islands did a Dutch-based Creole develop. In the same vein, it is not particularly surprising that a visitor to St. Thomas in the 1830s observed that Papiamentu was much spoken in this Danish colony-the language was brought there by migrants, both free and enslaved, arriving on the island from ailing Curaçao in the late eighteenth century. ${ }^{65}$

The implications are manifold and extend beyond the issue of culture and creolisation within the constituent parts of the Dutch Atlantic, which is in and of itself an extremely interesting topic. Economically and demographically, ethnic and cultural heterogeneity must have helped in shaping cross-imperial connections. At the same time, the internal heterogeneity may have affected the geopolitical cohesiveness and the interconnectedness of the Dutch Atlantic as a whole. We may wonder how this affected the emergence, or lack thereof, of a West Indian interest uniting all players with an economic interest in things Atlantic. For instance, there is little indication of the emergence of a Creole elite linking up with a West Indian interest in the Republic. ${ }^{66}$

As for the circulation of news and ideas, we may safely assume that these travelled relatively easily within the Atlantic and certainly also within the Republic and, hence, to the rest of Europe. Benjamin Schmidt has shown that pamphlets and broadsheets about the Americas had a lasting impact on the Dutch Republic - and not just on the elites-and spread from there to the rest of the continent. Thus the Republic remained the major producer of imagery of the Atlantic even as its own geopolitical presence declined, and, as such, continued to have a profound influence in the wider Atlantic world and beyond. On the other hand, we cannot be sure how this influenced public culture and mentalities within the Republic itself. The first question is, of course, how many within the Netherlands really learned about and/or had any personal relations with the Atlantic. Return migrants from the colonies might have cemented more classic imperial relations, but so far as we know return migration only involved small numbers of people. Surely the consumption of crucial Atlantic commodities such as sugar, coffee and tobacco increased, and the traction given to Dutch industry from these Atlantic endeavours generated employment opportunities for the working classes. But did this raise awareness of the Atlantic as a Dutch entity as a whole? Who else but upper- and middle-class absen- 
tee landowners, merchants and civil servants were really aware of the wider Dutch Atlantic? We have no idea. What we do know is that in the late eighteenth century there was nothing like the Atlantic awareness that propelled the British abolitionist movement.

\section{Periodisation}

The Atlantic requires its own periodisation. Most histories of early modern Europe end at 1789 and the French Revolution. However, ending studies of the Atlantic at this point bisects the so-called "Age of Revolution" in the Atlantic at a particularly vital point. As Donna Gabaccia points out, by the mid-eighteenth century, a long series of anti-colonial rebellions in North and South America, Europe, and the Caribbean had unfolded, and continued well into the nineteenth century in the Americas and Caribbean. ${ }^{67}$ Alison Games argues similarly when she notes that, "The Atlantic's age of revolution began in the British Atlantic world in the 1770s with the revolution that created the first republic in the Atlantic. It continued through the revolutions in France and Saint Domingue, the thwarted uprising of the United Irishmen, and into the early nineteenth century with the wars for independence in Latin America." ${ }^{68}$ In fact, Gabaccia argues for a much longer chronology for Atlantic history, in general. She believes that extending studies of Atlantic history into the nineteenth century makes far more sense. ${ }^{69}$

Along these lines of developing a separate periodisation for the Atlantic, two of the doyens of Atlantic history, Bernard Bailyn and John Elliott, have independently formulated tripartite chronologies of Atlantic history that are largely comparable. Bailyn terms the first an "era of contested marchlands" while Elliott calls it an "era of occupation." For Bailyn, the era of contested marchlands was dominated by violence and profound disorientation on the part of Europeans, Native Americans, and Africans. It was a period of extended, violently brutal, barbarous, genocidal conflict on contested marchlands or frontiers. ${ }^{70}$ For Elliott, this first phase of Atlantic history, beginning shortly after Columbus' voyage, was an age of intrusion, exploitation, devastation, and subjugation. Bailyn and Elliott both describe harsh confrontations with the native population, plundering, the institution of unfree labour, and the reconstruction and renaming of American spaces as hallmarks of this initial period of European engagement with the Atlantic. ${ }^{71}$ However, there were clear differences between the empires, as well. The Spanish occupation was based on dominating people and the construction of cities and towns, and was furthered by their practice of cohabitation with indigenous Americans. ${ }^{72}$ In contrast, this phase was, for the British, predicated on the commodification of land, was largely rural, and normalised the segregation of Europeans from Native Americans. ${ }^{73}$

The second stage is called "integration" by Bailyn and "consolidation" by Elliott. Both historians note growing integration and interdependence of the respective empires. There was an increasing uniformity and the assertion of metropolitan control from Spain and Britain, though Elliott notes the divergent trajectories of power between the Spanish and English during the second half of the seventeenth century. ${ }^{74}$ The last phase is one of "creole triumphalism" and "emancipation." Although there were clear differences between the Spanish and British empires in this phase, both historians see it in similar terms. It was an era of revolution, especially of revolutionary ideas, with societies growing and expanding their frontiers, which 
ultimately led to throwing off metropolitan control and the creation of new nations.

As cogent and convincing as Bailyn and Elliott's tripartite schemes are, the Dutch Atlantic does not fit into them. The first phases may have some merit when applied to the Dutch case, but the third-Creole triumphalism-is hardly applicable to the Dutch Atlantic at all. This is evident if one looks at the stagnation of Suriname's plantation economy beginning in the 1770s, the British take-over during the Napoleonic Wars, the subsequent decline of Curaçao and Statia, and the decrease of the slave trade resulting in the decline in the importance of Elmina dating from the last quarter of the eighteenth century, decades before abolition. The only lateeighteenth-century economic success story is Demerara, but this would soon become a British triumph, rather than a Dutch creole one.

In 2005, Jan de Vries proposed an alternative, four-phase, periodisation for Dutch economic activities in the Atlantic, of which three were situated in the early modern period. ${ }^{75}$ The Dutch started to explore the Atlantic in the late sixteenth century. In the initial years, which lasted until the founding of the WIC in 1621, Dutch trade in the Atlantic was driven by small private shipping companies. During the first phase (1621-54) the WIC conquered Northeast Brazil and several Portuguese trading posts in West Africa. But, in the long run, the company was unable to enforce a trade monopoly and to consolidate its Atlantic possessions. With debts piling up and a lack of military and political support at home, the WIC finally retreated from Brazil in 1654.

De Vries' second phase started after the loss of Brazil and lasted until 1713. During this period the Dutch diverted their attention to supplying other European colonies in the Atlantic with commodities and services. As a result of this policy, colonial products like sugar and tobacco kept arriving in the Republic. But at the end of the seventeenth century, the Dutch were ousted from this trade by English and French mercantilist measures. The final blow to the second phase was the loss in 1713 of the asiento, the monopoly over the slave trade to the Spanish colonies via Curaçao.

During de Vries' third phase, which lasted until the Fourth Anglo-Dutch War (1780-84), the Dutch chose to develop their own plantations in the Guyana region. However, unlike the English and French colonies, these did not benefit from a large and protected home market and their tropical products had to compete with the products of other European colonies on the Amsterdam market. According to de Vries, the fourth phase started at the end of the eighteenth-century and lasted until the present day. The main characteristic of this phase is a shift from trade to investment. For instance, since the 1780 s the Dutch have been major investors in the United States.

De Vries' scheme has the great advantage of favouring precision over undue aggregation and of focusing not simply on the Dutch empire, but rather on Dutch activities in the entire Atlantic. Nevertheless, we believe that, for all of its merits, this four-phase developmental scheme is in need of adjustment too. While de Vries suggests a succession of discrete phases, we propose that in the Dutch Atlantic, the second phase, the active and cross-empire engagement with the entire Atlantic trade, was to a large extent simultaneous with the third one, the construction and running of plantation economies. This simply reflects the diversity within the Dutch Atlantic. And incidentally, if we take the eighteenth-century Dutch cross-imperial 
commercial activities seriously, we can easily observe the continuity with de Vries' fourth phase.

\section{Framing a Dutch Atlantic Approach}

The previous section outlines what the existing historiography allows us to say about the defining characteristics of the Dutch Atlantic, including crucial developments and appropriate periodisations. But where does the study of the Dutch in the Atlantic fit in the burgeoning field of Atlantic history as a whole? After all, Atlantic history has been appearing ever more frequently in academic discourse for the past two decades. ${ }^{76}$ However, the Dutch do not seem to figure into this academic discourse much. The exception might be research into the Atlantic slave trade and the resultant analyses of the omnipresence of slavery in the early modern Americas, which is the area of Atlantic studies in which the Dutch are most conspicuous. ${ }^{77}$ As historian Alison Games has argued, colonial historians unhappy with the restrictions of looking exclusively at their "own" empires have also been at the forefront of creating Atlantic history; but Dutch colonial historians have not generally engaged with Atlantic history as a whole. ${ }^{78}$ What most of Atlantic history has in common is a strong North Atlantic, Anglo-American bias, which leaves out the Dutch, among others. This commonly heard critique has, to some extent, helped balance out the treatment of various other nations' endeavours in the Atlantic, a prime example being the more prominent place of the Iberian Atlantic in Atlantic studies. But this, of course, does not mean that all constituent parts of the Atlantic world are treated evenly, as is seen in the case of the Dutch, and it certainly does not mean that the interconnectedness of the entire Atlantic is actually analysed and contextualised.

Another line of criticism levelled at Atlantic history is that there is really nothing new about it at all, and that it is just a re-writing of European (and Eurocentric) history in a more politically correct manner. ${ }^{79}$ O'Reilly labels this "an attempt at replacing one European, or Anglo-Saxon, or First World, hermeneutic system of comprehending the past with another." 80 Along these lines, David Hancock issued his now famous warning that "The Atlantic history perspective, if it is to be anything more than boiled-over imperial history, must accentuate cross-boundary exchanges." ${ }^{81}$ With this statement, Hancock gets to the heart of the most frequently heard criticism of Atlantic history: a lack of accentuation, indeed, in some cases, a complete disregard, for the necessity of going beyond the boundaries of the nation-state. As Lara Putnam argues, historians have used the nation-state and national borders as "the default frame of reference and presumptive boundary of extrapolation," despite the fact that they are often superimposing such borders retroactively on historical realities that occurred long before the nation-state itself came into existence..$^{82}$ Even some of the most innovative approaches to Atlantic history continued to employ the nation-state as the frame of reference. ${ }^{83}$ Thus, Atlantic history continues to be studied and understood primarily from the perspective of Europe and viewed within a single imperial geography. ${ }^{84}$

What these critiques cogently suggest, is that the large geographic unit of the Atlantic itself, incorporating such a diversity of actors and including such a long chronology requires a different approach, focusing on commonalities, conver- 
gences, and patterns stemming from interactions. This method of inquiry is one that, by necessity, deemphasises any single place. As David Eltis asserts, "in the early modern Atlantic, for the first time in human history there appeared a hemispheric 'community' which was linked by economic, social and cultural networks". ${ }^{85}$ For J.H. Eliot, the real value of Atlantic history is that "It encourages historians to trace connections. But it also encourages them-or should encourage them-to draw comparisons." ${ }^{66}$

In essence, historians researching anything to do with the Atlantic these days are engaged in a complex balancing act. They must acknowledge what historians such as Peter Coclanis, Nicholas Canny, and Peter H. Wood, to name only a few, argue: that it does not make much sense to frame Atlantic history in terms of nations. ${ }^{87}$ These historians view Atlantic history as a tool for transcending traditional imperial approaches to history. Yet, ironically, as like-minded advocates of a non-national approach to the Atlantic Philip D. Morgan and Jack P. Greene point out, "The Atlantic as a whole may be too capacious an entity. Histories of the Atlantic world ...will always be extraordinarily difficult to accomplish; histories within the Atlantic world-invariably slices of it-inevitably will prove more manageable." 88 And here is summarised the heart of the paradox of engagement with Atlantic history. The basic tenets of Atlantic history argue against employing a national approach. Yet the exigencies of research make engaging in non-nationally-focused Atlantic history difficult, at best.

In line with the historiographical trends in the study of the Atlantic we have outlined above, we believe that the most fruitful approach to studying the Dutch in the Atlantic would be to take the focus away from the Dutch colonies per se, and, rather, emphasise the collection of Dutch actors and colonies and their connections to the wider Atlantic, while also questioning the very concept of "Dutchness" as it was understood in the Atlantic. It is, of course, not particularly new to state that the colonial "Dutch Atlantic" was anything but a cohesive and homogeneous entity. In fact, as we mentioned in the beginning of this article, in the late 1990s, Pieter Emmer and Wim Klooster, even argued that there was no Dutch Atlantic at all. ${ }^{89}$ But of course, there were Dutch colonies and connections in the Atlantic, and as the contributors to Riches from Atlantic Commerce make clear, the real and long underestimated importance of Atlantic commerce for the Dutch Republic was considerable. ${ }^{90}$ And, certainly, there is a large cultural legacy stemming from Dutch Atlantic endeavours - the production of maps, drawings, paintings, and other sources-not to mention the very idea of an Atlantic world itself emerging in the early modern period..$^{91}$

Indeed, as Jan de Vries postulated, the contradictory nature of the early modern "Dutch" Atlantic may offer us the perfect test of the viability of the very concept of an Atlantic world. ${ }^{92}$ Because we are studying the "expansion without empire" of the most loosely "national" of all states involved - that is, the most cosmopolitan, the least centralised, and so forth-we can study historical phenomena that were transatlantic, hemispheric, and transnational without falling into the trap of national narratives and the limitations characteristic of the historiographies of other nations' admittedly larger, and also more centralised, Atlantic enterprises. ${ }^{93}$ Moreover, by raising historical discussion of the Atlantic world to a level that not only incorporates but also transcends nations and empires, we have greater freedom to 
employ a variety of theoretical viewpoints for the writing of Atlantic history, and, in this sense, build on the existing historiography of the Dutch in the Atlantic and incorporate it in creating a new approach.

A particularly useful method for tracing such connections and drawing such comparisons, especially as applied to the Dutch in the Atlantic, is the "cis-Atlantic" approach advocated by David Armitage.${ }^{94}$ Armitage delineated "circum-Atlantic history," which examines the Atlantic experience as a whole; "trans-Atlantic history," which emphasises a comparative approach; and "cis-Atlantic history," as a method for locating a particular place, institution or commodity within an Atlantic context. Thus, when using a cis-Atlantic approach, historians can focus on a particular port city, an institution such as the Inquisition, or a particular commodity such as tobacco. ${ }^{95}$ But, most often, the cis-Atlantic perspective is used to interpret the history of a particular geographical entity - a nation, a state, a region-in relation to the wider Atlantic world. ${ }^{96}$ A particularly illustrative example of cis-Atlantic history is the Chaunus' monumental Séville et l'Atlantique, which tells the history of a particular city in relation to the Atlantic as a whole. ${ }^{97}$ Of course, this is not to say that circumand/or trans-Atlantic approaches are not applicable to the ways in Dutch nodal points functioned. They can be and are. Nevertheless, the cis-Atlantic approach seems to us to be most applicable to frame research on the Dutch in the Atlanticto begin with each Dutch nodal point and work outward to the larger whole in a cisAtlantic fashion.

Nodal points, as we define them, are the geographical framework for a starshaped network from whence prolonged connections were maintained with other hubs in the Atlantic. They were part of an integrated Atlantic network, and had a formal dimension (a set of rules and contracts) and an informal one (family contacts), as well as an illicit or extra-legal aspect, and commerce was one of the determining factors in their functioning. They are defined as "Dutch" if Dutch actors have played a primary role in the formation and operation of the nodal point. ${ }^{98}$ This means we would not consider as Dutch nodal points places where the Dutch did not exercise any formal control or did not govern the territory. By focusing on Dutch nodal points, we believe it will be possible to establish both what is unique and what is common in these particular places as the result of interactions and connections between the local and the greater whole. Dutch nodal points played a pivotal role in the exchange of goods and the study of nodal points certainly lends itself to economic analysis. Yet, as Jacob Price pointed out long ago, the study of nodal points goes beyond their economic relationships, especially with their respective metropoles. ${ }^{99}$ Price's analysis of these points incorporated the interweaving, comparison, and juxtaposition of not only commerce, but administration, people, and ideas. ${ }^{100}$ Moreover, Price brought to the fore the vital import of hinterlands to the functioning of nodal points, an insight we similarly believe should be integrated into analyses of the Dutch in the Atlantic. Ultimately, as Peggy Liss and Franklin Knight point out, "[Port] cities were far more than distribution points for the exchange of goods and services and foci of political control and imperial defence. Cities were rather the sum of the interaction of all these elements, centres of social and cultural differentiation." 101

Thus, we cannot limit ourselves to economic networks in port cities or nodal points. Our analysis should include demographic, social, cultural, intellectual, and 
political networks as well. Of course, the trouble with the concept of networks, to paraphrase David Hancock, is that its heuristic value cannot be overstated, as networks are often undermined by their component parts. ${ }^{102}$ For instance, as Hancock elucidates in his article on problematic networks, networks failed when problems arose among the parties involved in negotiating terms for sharing, monitoring agreements, responding to the all-too-frequent disasters that befell traders in the early modern Atlantic, and in estimating the actual costs of the transactions in which they engaged. ${ }^{103}$ Therefore, looking only at networks gives neither a full nor completely accurate picture of how the early modern Atlantic actually functioned. Additionally, of course, focusing on a specific middleman, network or commodity always implies the risk of getting lost in that particular story at the expense of contextualising the narrative in a broader Atlantic framework.

Ironically, in attempting to achieve as broad an Atlantic perspective as possible, we have closed the circle and come to believe in the importance of focusing on the regional as much as on the international. Looking at the Atlantic world as a whole, and on Dutch nodal points specifically, through the lens of nations or empires, leads to an approach that can divide the world in strange ways. For instance, if we look at Dutch nodal points such as Curaçao and St. Eustatius, or even any other island of the Caribbean, we see that each existed within its own imperial trajectory while sharing space with a rival power and participating in common regional transformations. What we need to establish, instead, is the degree to which supranational connections transcended colonial limitations, or even, perhaps, made these colonial borders obsolete. ${ }^{104}$ Certainly, there was a kaleidoscope of mutually opposing interests and often seemingly self-contradictory imperial impulses. ${ }^{105}$ As the work of Claudia Schnurmann illustrates, regional interests, loyalties, and, in the end, identities were often supra-national and trumped the artificial divisions imposed by national claims. ${ }^{106}$

With these various caveats in mind, we argue that the focus on nodal points will help us to demonstrate how the interests of individuals, groups, and regions were entangled in ever-shifting and often supra-national ways. By focusing on connections and interactions centred in and around these nodal points rather than on the nation-state as an over-arching and determining entity, we believe researchers will paint not only a more historically accurate picture, but also confront the paradox of studying the role of the Dutch in the Atlantic from a national perspective. In showcasing how Dutch ports functioned within a larger Atlantic world, we advocate an amalgamation of analytical approaches-network theory, port-city perspectives, regional foci, and what might ultimately be termed a multi-layered cis-Atlantic approach-for describing experiences and connections that were multiracial, multiethnic, multinational, and multi-imperial. Ultimately, our goal in advocating the employment of such a combination of approaches to analysing the Dutch in the Atlantic is to overcome artificial, but nonetheless enduring, divisions between histories usually distinguished from each other as internal and external, domestic and foreign, or national and imperial. ${ }^{107}$ For we recognise that every methodological construction and viewpoint that we take-connections and interactions, (cis)Atlantic, (Dutch) imperial, centre and periphery, European, Caribbean, South American, African, colonial, regional, networks, cities, ports-functions in slightly different ways, and each is relevant under different circumstances. They coexist and 
intersect, and all are necessary for understanding the reality of the Dutch in the Atlantic between roughly 1680 and $1800 .^{108}$

\section{Conclusions, Questions, Hypotheses}

We have argued that the need to overcome artificial divisions imposed by imperial geographies compels us to take an approach that goes beyond the traditional nationally-focused centre-and-periphery model of looking at the Atlantic. We believe in studying nodal points and their connections beyond the strictly colonial orbit, but we cannot escape the fact that the national, in this case the Dutch Republic, was responsible for major components of life in the Atlantic world, in general, and in Dutch nodal points specifically: components such as religious orientation, the system of law, modes of governance, economic policy, language, or architecture.

We hope that the framework we propose will help scholars in gaining a better understanding of the characteristics and overall significance of the "Dutch" Atlantic in early modern times. Of course, our focus on Dutch nodal points, middlemen, cross-imperial connections and networks implies that connectivity was more important than formal empire, at least in the Dutch case. Beyond this one salient fact, at this stage of research into the Dutch in the Atlantic between 1680 and 1800, there are as many questions as there are answers. Therefore, apart from a few tentative conclusions, this closing section offers hypotheses, suggestions and questions centred within the framework for analysing the Dutch in the Atlantic which we have proposed in this article.

For instance, in the economic realm, one clear question has emerged: how were the Dutch able to acquire a substantial part of Atlantic shipping and trade without having a colonial empire? Perhaps a synthesis of information from various Dutch nodal points can help in answering this question. Characteristic of the Dutch Atlantic economy was the WIC's weak central organisation, which was in clear contrast to the tight organisational structure of the VOC. Moreover, trade and finance operated in a series of only partially interlinking networks. The Dutch colonies maintained strong connections with non-Dutch parts of the (wider) Caribbean. The North American link was perhaps measurably of even greater significance, as was the direct Dutch link to the North American colonies. There were certainly changes over time in the intensity of the various connections, but researchers are still in the process of quantifying these. What is clear is that geographical differences translated into divergent economic models and migration patterns. The immediate hinterlands were of little economic significance in the Caribbean territories, unless, of course, we consider the surrounding non-Dutch colonies as hinterlands of Curaçao and Statia. Hinterlands were of more importance to the early American possessions, and they were crucial both for Elmina and for the Republic itself. The divergence in patterns of economic growth between the various overseas Dutch settlements reflected differences in natural resources and, therefore, their resulting economic character (primarily oriented to trade or to production of tropical staples) but also shifting opportunities over time throughout the Atlantic (for example Curaçao versus Statia and Suriname versus Demerara).

In trying to establish a periodisation for the entire Dutch Atlantic, we need to take this chronological variability into account. For all of its merits, the periodisation 
advanced by Jan de Vries is in need of refining. What approach may be helpful for establishing an empirically more nuanced chronology of the Dutch Atlantic and its internal and external connections? We could start by charting developments over time for each of the various nodal points, including indications for the intensity of external connections over time. As an alternative approximation, it is possible to do the same for particular parameters (trade, migration and demographics, investments, books or maps produced, and the like). On the basis of such exercises, we may aspire to mapping the entire "Dutch" Atlantic and its connections over time and comparing the resulting dynamic analysis to periodisations advanced for the wider Atlantic. Whether this is possible within the framework we propose for studying the Dutch in the Atlantic remains to be seen. Whatever system of periodisation we employ the fact remains that, within the Republic, structural changes in the national economy were partly linked to the vicissitudes of the wider Atlantic economy. In contrast to earlier received wisdom, it seems clear that the growth of Dutch Atlantic shipping and finance was superior to the overall economic development of Dutch international trade in this period. The question remains whether this growth was on a par with Atlantic growth for other nations.

We do know that after its short-lived Golden Age the Republic was no longer a major military power. The stability of the Dutch Atlantic was, therefore, highly dependent on the nature of its relations with the British, French and Spanish. The long century between the Third (1672-74) and Fourth (1780-84) Anglo-Dutch Wars was remarkably tranquil, and the neutrality of the Republic facilitated the brokering role of Dutch colonies and middlemen. The Fourth Anglo-Dutch War as well as the era of the French Revolutionary and Napoleonic Wars exposed the fragility of the Dutch Atlantic. (Indigenous and slave resistance were never absent, but these were only on a few occasions potentially fatal.) Moreover, the Dutch Atlantic trade zones straddled the boundaries of mercantilism. This applies not only to Curaçao and Statia, but equally to the Dutch-dominated alternative of Danish St. Thomas. Such islands served a useful function for all the Atlantic sub-empires until the demise of mercantilism, and became superfluous afterwards.

In terms of cultural and demographic interactions, it seems clear that, with the exception of Elmina, the Dutch Atlantic colonies were all immigrant societies with different proportions of European, African and, increasingly, Eurafrican inhabitants. Numerically, the indigenous population was only of some significance in the Guianas. The degree of interracial mixing varied from colony to colony and was highest in Curaçao. By comparative Atlantic standards, the European segment in all Dutch colonies was remarkably cosmopolitan. This heterogeneity had implications for the emergence and maintenance of external networks, but also for patterns of creolisation. The diversity within the European segments of the population corresponded with a pragmatic toleration for religious diversity among the free population, but also illustrates contrasting ideas about, and practices of, Christianising the slave populations. There is little indication that the diverse national and religious background of the European and/or white Creole population created divided loyalties among the white population, with the glaring exception of late eighteenthcentury Demerara with its large British contingent.

Ultimately, one challenge is to establish whether the framework we have set down makes sense as a methodology for approaching the study of the Dutch in the 
Atlantic between 1680 and 1800 . But there is quite another, larger challenge which emerges from this approach as well. And that is to question whether any of this is really uniquely Dutch at all. Is the purported importance of the Dutch in the Atlantic as middlemen, brokers, and cultural and economic intermediaries a question of a slight difference in scale from that of other nations, or was there really a qualitative difference? In answering this question, it may help to think not only of the intensity, but also of the design, of networks. There is a case for stating that the Dutch Atlantic was highly decentralised, like a spider web rather than the typical hub-andspoke. Again, this begs the question of whether this metaphor is correct, but also whether this would be indicative of a singular Dutch Atlantic "model." Whether they employ our framework or not, future discussions of the Dutch in the Atlantic need to reflect on the extant historiography of the wider Atlantic: on how Dutch Atlantic connections are represented, the nature of the distortions and lacunae, and whether a fresh look at the Dutch in the Atlantic may inspire a re-evaluation of Atlantic history at large. With Peter Coclanis' argument for a "conjuncto-Atlantic" approach in mind, perhaps this may also inspire some of us to rethink the relevance of the "Dutch-in-the- Atlantic" experience for our understanding of world history at large. ${ }^{109}$ 


\section{Bibliography of Works Cited}

\section{Primary Sources}

Censuses of Canada, 1665 to 1871, Statistics of Canada, vol. 4 (Ottawa, 1876). Accessible online on http://www.statcan.gc.ca/pub/98-187-x/4198820-eng.pdf [accessed on 30 May 2012].

A Century of Population Growth in the United States, 1790-1900, publication of the Department of Commerce and Labor, Bureau of the Census (Washington, 1909).

\section{Secondary Sources}

Andrews, Charles. The Colonial Period of American History. New Haven: Yale University Press, 193438.

Armitage, David. "Three Concepts of Atlantic History." In The British Atlantic World, 1500-1800, ed. David Armitage and Michael J. Braddick, 11-27. Basingstoke: Palgrave Macmillan, 2002.

- and Michael J. Braddick, eds. The British Atlantic World, 1500-1800. Basingstoke: Palgrave Macmillan, 2002.

Bailyn, Bernard, Atlantic History: Concept and Contours. Cambridge: Harvard University Press, 2005.

—. "The Idea of Atlantic History." Itinerario 20:2 (1996): 19-44.

"The World-Island, and the Idea of Atlantic History." Journal of World History 13 (2002): 169-82.

Bolster, W. Jeffrey, Black Jacks. African American Seamen in the Age of Sail. Cambridge: Harvard University Press 1997.

Boogaart, Ernst van den, and Piet Emmer, eds. La expansión holandesa en el Atlántico, 1580-1800. Madrid: Editorial MAPFRE, 1992.

Bosch, G.B. Reize in West-Indië. Vol. 1. Utrecht, 1829-36.

Brodhead, John Romey. History of the State of New York. New York, 1872.

Butel, Paul. "France, the Antilles, and Europe in the Seventeenth and Eighteenth Centuries: Renewals of Foreign Trade." In The Rise of Merchant Empires: Long-distance Trade in the Early Modern World, 1350-1750, ed. James D. Tracy, 153-73. Cambridge: Cambridge University Press, 1993.

Canizares-Esguerra, Jorge. "AHR Forum: Entangled Histories: Borderland Historiographies in New Clothes?" The American Historical Review (June 2007) < http://www.historycooperative.org/ journals/ ahr/112.3/canizaresesguerra.html> (9 Mar. 2012).

Canny, Nicholas. "Atlantic History and Global History." In Atlantic History: A Critical Appraisal, ed. Jack P. Greene and Philip D. Morgan, 317-36. New York: Oxford University Press, 2009.

Chaunu, H., and P. Chaunu, Séville et l'Atlantique (1504-1650). 12 vols. Paris: S.E.V.P.E.N., 1955-60.

Coclanis, Peter. "Atlantic World or Atlantic/World?" William and Mary Quarterly 63 (2006): 725-42.

Coclanis, Peter A. "Beyond Atlantic History." In Atlantic History: A Critical Appraisal, ed. Jack P. Greene and Philip D. Morgan, 337-56. New York: Oxford University Press, 2009.

Coclanis, Peter. "Drang Nach Osten: Bernard Bailyn, the World-Island, and the Idea of Atlantic History." Journal of World History 13 (2002): 169-82.

Cohen, Robert. Jews in an Another Environment: Surinam in the Second Half of the Eighteenth Century. Leiden: Brill, 1991.

Costigan, Lúcia Helena. Through Cracks in the Wall: Modern Inquisitions and New Christian Letrados in the Iberian Atlantic World. Leiden: Brill, 2010.

Cruz, Laura E. "For Richer or for Poorer: The Promise and Limitations of Dutch Atlantic History." Review of Johannes Postma and Victor Enthoven, eds. Riches from Atlantic Commerce: Dutch Transatlantic Trade and Shipping, 1585-1817, H-Atlantic (April 2005).

Curtin, Philip D. The Atlantic Slave Trade: A Census. Madison: University of Wisconsin Press, 1969.

Devine, T.M. Scotland's Empire, 1600-1815. London: Penguin, 2004.

Dubois, Lauren. "The French Atlantic." In Atlantic History: A Critical Appraisal, ed. Jack P. Greene and Philip D. Morgan, 137-61. New York: Oxford University Press, 2009.

Elliott, John. "Afterword, Atlantic History: A Circumnavigation." In The British Atlantic World, 15001800, ed. David Armitage and Michael J. Braddick, 233-49. Basingstoke: Palgrave Macmillan, 2002.

. Empires of the Atlantic: Britain and Spain in America, 1492-1830. New Haven: Yale University Press, 2006.

Eltis, David. "Atlantic History in Global Perspective." Itinerario 23:2 (1999): 141-61.

- The Rise of African Slavery in the Americas. Cambridge: Cambridge University Press, 2000. 
Emmer, Pieter C. The Dutch in the Atlantic Economy, 1580-1880. Aldershot: Ashgate, 1998.

. "The Myth of Early Globalization: The Atlantic Economy, 1500-1800." European Review 11 (2003): 37-47.

—. The Dutch Slave Trade, 1500-1850. Oxford: Berghahn, 2006.

__ and Wim Klooster. "The Dutch Atlantic, 1600-1800: Expansion without Empire." Itinerario 23:2 (1999): 48-69.

Enthoven, Victor. "An Assessment of Dutch Transatlantic Commerce, 1585-1817." In Riches from Atlantic Commerce: Dutch Transatlantic Trade and Shipping, 1585-1817, ed. Victor Enthoven and Johannes Postma, 385-445. Leiden: Brill, 2003.

. "Dutch Crossings: Migration between the Netherlands and the New World, 1600-1800." Atlantic Studies 2:2 (2005): 153-76.

. "Going Dutch: Interloping in the Dutch Atlantic World." In Small is Beautiful? Interlopers and Smaller Trading Nations in the Pre-industrial Period: Proceedings of the XVth World Economic History Congress in Utrecht (Netherlands) 2009, ed. Markus A. Denzel, Jan de Vries, and Philipp Robinson Rössner, 21-48. Stuttgart: Steiner, 2011.

— . "That Abominable Nest of Pirates: St. Eustatius and the North Americans, 1680-1780." Early American Studies 10:2 (2012): 239-301.

_ and Henk den Heijer. "Nederland en de Atlantische wereld, 1600-1800: een historiografisch overzicht." Tijdschrift voor Zeegeschiedenis 24:2 (2005): 147-66.

and Johannes Postma, eds. Riches from Atlantic Commerce: Dutch Transatlantic Trade and Shipping, 1585-1817. Leiden: Brill 2003.

Esteban, Javier Cuenca. "Comparative Patterns of Colonial Trade: Britain and its Rivals." In Exceptionalism and Industrialisation: Britain and Its European Rivals, 1688-1815, ed. Leandro Prados de la Esocosura, 35-66. Cambridge: Cambridge University Press, 2004.

Faber, J.A., et al. "Population Changes and Economic Development in the Netherlands: A Historical Survey." A.A.G. Bijdragen 12 (1965): 47-113.

Fatah-Black, Karwan, and Matthias van Rossum. "Wat is winst? De economische impact van de Nederlandse trans-Atlantische slavenhandel." Tijdschrift voor Sociale en Economische Geschiedenis 9:1 (2012): 3-29.

Fortune, Stephen Alexander, Merchants and Jews: The Struggle for British West Indian Commerce, 1650-1750. Gainesville: University of Florida Press, 1984.

Gabaccia, Donna. "A Long Atlantic in a Wider World." Atlantic Studies 1:1 (2004): 1-27.

Games, Alison. "Atlantic History: Definitions, Challenges, and Opportunities." American Historical Review 111:3 (2006): 741-57.

- "Atlantic Ocean" Europe, 1450 to 1789: Encyclopedia of the Early Modern World. 2004. Encyclopedia.com. 1 Mar. 2012 <http://www.encyclopedia.com>

. "Beyond the Atlantic: English Globetrotters and Transoceanic Connections." William and Mary Quarterly 63 (2006): 675-92.

- "Migration." In The British Atlantic World, 1500-1800, ed. David Armitage and Michael J. Braddick, 31-50. Basingstoke: Palgrave Macmillan, 2002.

Goodfriend, Joyce D. Before the Melting Pot: Society and Culture in Colonial New York City, 16641730. Princeton: Princeton University Press, 1992.

_. "Foreigners in a Dutch Colonial City." New York History (Fall 2009) < http://www.historycooperative.org/journals/nyh/90.4/goodfriend.html> (27 Feb. 2012.

- Benjamin Schmidt, and Annette Stott, eds. Going Dutch: The Dutch Presence in America, 1609-2009. Leiden: Brill, 2008.

Goslinga, Cornelis. The Dutch in the Caribbean and on the Wild Coast, 1580-1680. Assen: Van Gorcum, 1971.

Greene, Jack P. "Hemispheric History and Atlantic History." In Atlantic History: A Critical Appraisal, ed. Jack P. Greene and Philip D. Morgan, 299-316. New York: Oxford University Press, 2009.

- Pursuits of Happiness: The Social Development of Early Modern British Colonies and the Formation of American Culture. Chapel Hill: University of North Carolina Press, 1988.

Hancock, David. "The British Atlantic World: Co-ordination, Complexity, and the Emergence of an Atlantic Market Economy, 1651-1815." Itinerario 23:2 (1999): 107-26.

—. "The Trouble with Networks: Managing the Scots' Early-Modern Madeira Trade." Business History Review 79:3 (2005): 467-91. 
Haring, Clarence. The Spanish Empire in America. New York: Oxford University Press, 1947.

Hatfield, April Lee. Atlantic Virginia: Intercolonial Relations in the Seventeenth Century. Philadelphia: University of Pennsylvania Press, 2004.

- "Dutch Merchants and Colonists in the English Chesapeake Trade: Migration and Nationality in 17th-Century Maryland and Virginia." In From Strangers to Citizens: The Integration of Immigrant Communities in Britain, Ireland, and Colonial America, 1550-1750, ed. Randolph Vigne and Charles Littleton, 206-305. London: The Huguenot Society of Great Britain, 2001.

Heijer, Henk den. "Een dienaar van vele heren: De Atlantische carrière van Hendrick Caerloff." In Het Verre Gezicht: Politieke en culturele relaties tussen Nederland en Azië, Afrika en Amerika, ed. J. Thomas Lindblad and Alicia Schrikker, 162-80. Franeker: Van Wijnen, 2011.

. De geschiedenis van de WIC. Zutphen: Walburg Pers, 1994.

and Karwan Fatah-Black. "The Dutch in the Atlantic: A Shifting History from Empire to Networks and Nodal Points." Unpublished paper.

Herzog, Tamar. Defining Nations: Immigrants and Citizens in Early Modern Spain and Spanish America. New Haven: Yale University Press, 2003.

Higman, B.W. Slave Populations of the British Caribbean, 1807-1834. 1984. Reprint Kingston, 1995. Israel, Jonathan. Dutch Primacy in World Trade, 1585-1740. Oxford: Oxford University Press, 1989.

Jacobs, Jaap. New Netherland: A Dutch Colony in Seventeenth-Century America. Leiden: Brill, 2005. Jong, T.P.M de. De krimpende horizon van de Hollandse kooplieden: Hollands welvaren in het Caribisch Zeegebied, 1780-1830. Assen: Van Gorcum, 1966.

Jordaan, Han. Personal communication, April 24, 2012.

- Slavernij en vrijheid op Curaçao: de dynamiek van een achttiende-eeuws Atlantisch handelsknooppunt. PhD diss., University of Leiden, 2012.

Klooster, Wim. "Anglo-Dutch Trade in the Seventeenth Century: An Atlantic Partnership?" In Shaping the Stuart World, 1603-1714: The Atlantic Connection, ed. Allan I. Macinnes and Arthur H. Williamson, 261-84. Leiden: Brill, 2006. Illicit Riches: Dutch Trade in the Caribbean, 1648-1795. Leiden: KITLV Press, 1998.

"Other Netherlands beyond the Sea: Dutch America between Metropolitan Control and Divergence, 1600-1795." In Negotiated Empires: Centers and Peripheries in the Americas, 15001820, ed. Christine Daniels and Michael V. Kennedy, 171-92. New York: Routledge, 2002.

—. "An Overview of Dutch Trade with the Americas, 1600-1800." In Riches from Atlantic Commerce: Dutch Transatlantic Trade and Shipping, 1585-1817, ed. Victor Enthoven and Johannes Postma, 365-83. Leiden: Brill 2003.

- Private correspondence, 1 February 2002.

Knight, David W., and Laurette de T. Prime, eds. St. Thomas 1803, Crossroads of the Diaspora: The 1803 Proceedings and Register of the Free Coloured Inhabitants in the Town of Charlotte Amalie, on the Island of St. Thomas in the Danish West Indies. St. Thomas, VI: Little Northside Press, 1999.

Kossmann, E.H. "The Dutch Republic in the Eighteenth Century." In The Dutch Republic in the Eighteenth Century: Decline, Enlightenment, and Revolution, ed. Margaret C. Jacob and Wijnand W. Mijnhardt, 19-31. Ithaca: Cornell University Press, 1992.

Kruijtzer, Gijs. "European Migration in the Dutch sphere." In Dutch Colonialism, Migration and Cultural Heritage, ed. Gert Oostindie, 97-154. Leiden: KITLV Press, 2008.

—. Xenophobia in Seventeenth-Century India. Leiden: Leiden University Press, 2009.

Lesger, Clé. "Stagnatie en stabiliteit: De economie tussen 1730 en 1795." In Geschiedenis van Amsterdam, 1650-1813, ed. Willem Frijhoff and Maarten Prak, vol. 2.219-65. Amsterdam: SUN, 2005.

Liss, Peggy K., and Franklin W. Knight. "Introduction." In Atlantic Port Cities: Economy, Culture, and Society in the Atlantic World, 1650-1850, ed. Peggy K. Liss and Franklin W. Knight, 1-12. Knoxville, University of Tennessee Press, 1991.

Lucas, Henry S. Netherlanders in America: Dutch Immigration to the United States and Canada, 1789-1950. Ann Arbor: University of Michigan Press, 1955.

Mancke, Elizabeth. The Creation of the British Atlantic World. Baltimore: Johns Hopkins University Press, 2005.

Mandelblatt, Bertie. "A Transatlantic Commodity: Irish Salt Beef in the French Atlantic World." History Workshop Journal, 63:1 (2007): 18-47.

Meinig, D.W. The Shaping of America: A Geographical Perspective on 500 Years of History. Vol. 1, Atlantic America. New Haven: Yale University Press, 1986. 
Menkman, W.R. De Nederlanders in het Caraibische zeegebied waarin vervat de geschiedenis der Nederlandsche Antillen. Amsterdam: P. N. van Kampen, 1942.

Miranda, Bruno Romero Ferreira. Gente de Guerra: origem cotidiano e resistência dos soldados do exército da companhia das índias ocidentais no Brasil (1630-1654). PhD diss., University of Leiden, 2011.

Morgan, Philip D., and Jack P. Greene. "Introduction: The Present State of Atlantic History." In Atlantic History: A Critical Appraisal, ed. Greene and Morgan, 3-33. New York: Oxford University Press, 2009.

Norton, Marcy. Sacred Gifts, Profane Pleasures: A History of Tobacco and Chocolate in the Atlantic World. Ithaca: Cornell University Press, 2008.

O'Callaghan, E.B. History of New Netherlands; or, New York under the Dutch. New York: D. Appleton E Co., 1846.

O'Neill, Peter D., and David Lloyd, eds. The Black and Green Atlantic: Cross-Currents of the African and Irish Diasporas. London: Palgrave, 2009.

O'Reilly, William. "Genealogies of Atlantic History." Atlantic Studies 1:1 (2004): 66-84.

Oostindie, Gert. Roosenburg en Mon Bijou: Twee Surinaamse plantages, 1720-1870. Leiden: KITLV Press, 1989.

—. "'British Capital, Industry, and Perseverance' vs. Dutch 'Old School'? The British Takeover of Berbice, Demerara and Essequibo, 1750-1815.” BMGN/Low Countries Historical Review 127:4 (2012) [forthcoming].

and Rosemarijn Hoefte. "Historiography of Suriname and the Netherlands Antilles." In General History of the Caribbean. Vol. 5, Methodology and Historiography of the Caribbean, ed. B.W. Higman, 604-30. London: UNESCO/Macmillan, 1999.

Pluchon, Pierre. Histoire des Antilles et de la Guyana. Toulouse: Privat, 1982.

Postma, Johannes. The Dutch in the Atlantic Slave Trade, 1600-1815. Cambridge: Cambridge University Press, 1990.

Price, Jacob. "Economic Function and the Growth of American Port Towns in the Eighteenth Century." Perspectives in American History 8 (1974): 121-86.

Pritchard, James. In Search of Empire: The French in the Americas, 1670-1730. Cambridge: Cambridge University Press, 2004.

Putnam, Lara. "To Study the Fragments/Whole: Microhistory and the Atlantic World." Journal of Social History 39 (2006): 615-30.

Raynal, Ghuillaume Th.F. Histoire philosophique et politique, des établissements du commerce des Européens dans les deux Indes. 6 vols. 4.246-48. Amsterdam, 1770.

Rees, O. Van. Geschiedenis der Staathuishoudkunde in Nederland tot het einde der achttiende eeuw. 2 vols. Utrecht: Kemink en Zoon, 1865-68.

Rink, Oliver. Holland on the Hudson: An Economic and Social History of Dutch New York. Ithaca: New York State Historical Society, 1986.

Schalkwijk, Jan Marten. The Colonial State in the Caribbean: Structural Analysis and Changing Elite Networks in Suriname, 1650-1920. The Hague: Amrit, 2011.

Schmidt, Benjamin. Innocence Abroad: The Dutch Imagination and the New World, 1570-1670. Cambridge University Press, 2001.

- Joyce D. Goodfriend, and Annette Stott. "Holland in America." In Going Dutch: The Dutch Presence in America, 1609-2009, ed. Goodfriend, Schmidt, and Stott, 1-26. Leiden: Brill, 2008.

Schnurmann, Claudia. "Atlantic Trade and American Identities." In Atlantic History: History of the Atlantic System, 1580-1830, ed. Horst Pietschmann, 179-98. Göttingen: Vandenhoeck E Ruprecht, 2002.

. "Atlantic Trade and American Identities: The Correlations of Supranational Commerce, Political Opposition, and Colonial Regionalism." In The Atlantic Economy during the Seventeenth and Eighteenth Centuries: Organization, Operation, Practice, and Personnel, ed. Peter A. Coclanis, 186-204. Columbia: University of South Carolina Press, 2005.

—. "The Dutch in the Atlantic: From Henry Hudson to the War of Spanish Succession." Unpublished paper presented at the "Four Centuries of Dutch-American Relations" conference, Vrije Universiteit, Amsterdam, 15-16 October 2009.

Scott, Julius. The Common Wind: Currents of Afro-American Communication in the Era of the Haitian Revolution. PhD diss., Duke University, 1986.

Smith, Adam. An Inquiry into the Nature and Causes of the Wealth of Nations, ed. R.H. Campbell, A.S. 
Skinner, and W.B. Todd. 2 vols. Indianapolis: Liberty Fund, 1981.

Stipriaan, A. van. Surinaams contrast: roofbouw en overleven in een Carïbische plantagekolonie 1750-1863. Leiden: KITLV Press, 1993.

Voort, J.P. van der. De Westindische plantages van 1720 tot 1795. Financiën en handel. Eindhoven: Drukkerij de Witte, 1973.

Vries, Jan de. "The Dutch Atlantic Economies." In The Atlantic Economy during the Seventeenth and Eighteenth Centuries: Organization, Operation, Practice, and Personnel, ed. Peter A. Coclanis, 1-29. Columbia: University of South Carolina Press, 2005.

710-33

. "The Limits of Globalization in the Early Modern World." Economic History Review 63:3 (2010):

and Ad van der Woude. The First Modern Economy: Success, Failure, and Perseverance of the Dutch Economy, 1500-1815. Cambridge: Cambridge University Press, 1997.

. Nederland 1500-1815, de eerste ronde van moderne economische groei. Amsterdam:

Balans, 1995.

Wood, Peter H. "From Atlantic History to a Continental Approach." In Atlantic History: A Critical Appraisal, ed. Jack P. Greene and Philip D. Morgan, 279-98. Oxford: Oxford University Press, 2009. 


\section{Notes}

* Gert Oostindie is professor of Caribbean History at the University of Leiden and Director of the Royal Netherlands Institute of Southeast Asian and Caribbean Studies (KITLV). Jessica Vance Roitman is a lecturer in Early Modern History at the University of Leiden and a post-doctoral researcher at the KITLV where she works on the Dutch Research Council (NWO) funded "Dutch Atlantic Connections" project.

1 Itinerario 23:2 (1999). See the collection of articles on "The Nature of Atlantic History," the proceedings of a round table conference, pp. 48-173. [ Emmer and Klooster, "The Dutch Atlantic, 1600-1800: Expansion without Empire," 48-69. We gratefully acknowledge the constructive comments on an earlier version of this article given by the participants in the "Dutch Atlantic Connections" symposium (Leiden, KITLV, 23-24 August 2012) as well as by the anonymous reviewers for Itinerario.

2 Armitage, "Three Concepts of Atlantic History," 11-27, 22.

3 Den Heijer and Fatah-Black, "The Dutch in the Atlantic: A Shifting History from Empire to Networks and Nodal Points," 4.

4 Meinig, The Shaping of America, 62.

5 To name only a few, see the essays in Enthoven and Postma, eds., Riches from Atlantic Commerce; Emmer, The Dutch Slave Trade; Klooster, Illicit Riches; Emmer and Klooster, "The Dutch Atlantic, 1600-1800;" Schmidt, Innocence Abroad; Van den Boogaart and Emmer, eds., La expansión holandesa en el Atlántico, 1580-1800; and Emmer, The Dutch in the Atlantic Economy.

6 Enthoven and Postma, "Introduction," in Riches from Atlantic Commerce, 1-13, 1.

7 Ibid., 6-7.

8 See, however, Oostindie, "'British Capital, Industry, and Perseverance' vs. Dutch 'Old School'?."

9 For Dutch Caribbean historiography, see Oostindie and Hoefte, "Historiography of Suriname and the Netherlands Antilles, 604-30; Van der Voort, De Westindische plantages van 1720 tot 1795; Oostindie, Roosenburg en Mon Bijou; Van Stipriaan, Surinaams contrast.

10 Enthoven and Postma, "Introduction," 6-10.

11 Enthoven and Den Heijer, "Nederland en de Atlantische wereld, 1600-1800: een historio- grafisch overzicht," 147-66, 148-9.

12 Israel, Dutch Primacy.

13 Ibid., 393-7. For books espousing a differing view, see Menkman, De Nederlanders in het Caraibische zeegebied, 129-31, and De Jong, De krimpende horizon van de Hollandse kooplieden.

14 Postma, The Dutch in the Atlantic Slave Trade.

15 Van den Boogaart and Emmer, eds., La expansión holandesa en el Atlántico.

16 Emmer, The Dutch in the Atlantic Economy.

17 Ibid., 1.

18 Emmer, The Dutch Slave Trade, 1500-1850.

19 This view has recently been treated by Fatah-Black and Van Rossum in "Wat is winst? De economische impact van de Nederlandse trans-Atlantische slavenhandel," 3-29.

20 De Vries and Van der Woude, The First Modern Economy, 402.

21 Ibid., 467-77.

22 lbid.

23 Ibid.

24 De Vries, "The Dutch Atlantic Economies," 1-29, 2.

25 Ibid.

26 Ibid., 18.

27 Ibid., 19.

28 De Vries, "The Limits of Globalization in the Early Modern World," 710-33, 728.

29 Lesger, "Stagnatie en stabiliteit: De economie tussen 1730 en 1795," 219-65, 220.

30 Enthoven and Den Heijer, "Nederland en de Atlantische wereld, 1600-1800," 147-66.

31 Klooster, Illicit Riches.

32 Klooster, private correspondence, 1 February 2002.

33 Jacobs, New Netherland: A Dutch Colony in Seventeenth-Century America. Goodfriend, "Foreigners in a Dutch Colonial City;" Goodfriend, Schmidt, and Stott, eds., Going Dutch; and Goodfriend, Before the Melting Pot.

34 See, among others, Hatfield, Atlantic Virginia and "Dutch Merchants and Colonists in the English Chesapeake Trade, 206-305; Schnurmann, "Atlantic Trade and American Identities," 186-204.

35 Schnurmann, "Atlantic Trade and American Identities."

36 Schmidt, Innocence Abroad; and Goodfriend, Schmidt, and Stott, eds., Going Dutch.

37 Klooster, "Other Netherlands Beyond the Sea," 171-92.

38 Cruz, "For Richer or for Poorer." 
39 There is a long historiography on patroonschappen, much of it equating them with feudalism. See Brodhead, History of the State of New York; O'Callaghan, History of New Netherlands; and Rink, Holland on the Hudson. Jan de Vries addresses these views in "The Dutch Atlantic Economies," 17. Other European nations employed this method of settling their overseas territories. Portugal used a system of so-called "captaincies," and the English gave large grants of land to individual settlers and/or consortiums of investors to arrange for the colonisation of vast swathes of territory.

40 Den Heijer, De geschiedenis van de WIC, 28-34; Kossmann, "The Dutch Republic in the Eighteenth Century.," 19-31.

41 See Israel, Dutch Primacy in World Trade and De Vries and Van der Woude, The First Modern Economy.

42 Raynal, Histoire philosophique et politique, 4:246-48 and Smith, An Inquiry into the Nature and Causes of the Wealth of Nations, 2:571. See also Enthoven, "That Abominable Nest of Pirates," 239-301, 294.

43 Though the WIC pulled out of the slave trade officially after 1730 , some slaving ships still sailed to Curaçao. Between 1730 and 1740, there was only one known WIC slaving mission to Curaçao. But during the next decade, there was a revival in the slave trade. Between 1740 en 1751, at least five more WIC slave ships were sent to Curaçao. Han Jordaan, personal communication, April 24, 2012.

44 Klooster, "An Overview of Dutch Trade with the Americas, 1600-1800," 365-83, 382-3.

45 Klooster, Illicit Riches, 176, table 7.

46 See De Vries and Van der Woude, "The Dutch Atlantic Economies," and "Globalization in the Early Modern World;" Klooster, Illicit Riches and "An overview;" and Enthoven, "An Assessment of Dutch Transatlantic Commerce, 1585-1817," in Enthoven and Postma, eds., Riches from Atlantic Commerce, 385-445. We thank Gerhard de Kok for helping us compile the most relevant sources on this issue.

47 Enthoven, "Going Dutch. Interloping in the Dutch Atlantic World," 21-48.

48 De Vries, "The Dutch Atlantic Economies," 19; Enthoven, "An Assessment of Dutch Transatlantic Commerce," 441; see also Klooster, "An Overview," 379.

49 De Vries, "The Dutch Atlantic Economies," 19; Enthoven, "An Assessment of Dutch Transatlantic Commerce," 443. See also Klooster, "An Overview," 379; Butel, "France, the Antilles, and Europe in the Seventeenth and Eighteenth Centuries: Renewals of Foreign Trade," 153-73, 170; Cuenca Esteban, "Comparative Patterns of Colonial Trade: Britain and its Rivals," 35-66, 38-9; and Van der Voort, De Westindische plantages, 135.

50 In the Guianas, in Berbice, Demerara, and Essequibo more so than in Suriname, the Amerindian population did survive in appreciable numbers, but lived mainly in the interior.

51 Enthoven, "Dutch Crossings: Migration between the Netherlands and the New World, 1600-1800," 153-76, 165; Kruijtzer, "European Migration in the Dutch sphere," 97-154, 108. We thank Gerhard de Kok for undertaking the literature research for these and subsequent paragraphs.

52 Lucas, Netherlanders in America, 19.

53 Faber, et al., "Population Changes and Economic Development in the Netherlands," 47-113, 110; cited in De Vries and Van der Woude, The First Modern Economy, 50.

54 Games, "Migration," 31-50, 41; Greene, Pursuits of Happiness, 179. About $90 \%$ of the white population of British America lived in what became the United States of America after 1776 . The figure of 465,000 is a very approximate one, based on a rough estimate of 400,000 whites in Canada (including formerly French Canada, gained by Britain in 1765) and 65,000 whites in the British Caribbean colonies. See, A Century of Population Growth in the United States 1790-1900, publication of the Department of Commerce and Labor, Bureau of the Census (Washington 1909), 80; Higman, Slave Populations of the British Caribbean, 76-7; Document "Statistics of Canada," accessible online on http://www.statcan.gc.ca/pub/98187-x/4198820-eng.pdf [accessed on 30 May 2012]. Taken from Censuses of Canada.

55 See Pritchard, In Search of Empire, 16-17; Pluchon, Histoire des Antilles et de la Guyana; and Dubois, "The French Atlantic," 137-61, 139.

56 Eltis, The Rise of African Slavery in the Americas, 9. His figures are as follows: Britain 746,000; Spain 678,000; Portugal 523,000; France 100,000; the Netherlands 20,000.

57 Schnurmann, "The Dutch in the Atlantic: From Henry Hudson to the War of Spanish Succession," unpublished paper presented at the "Four Centuries of Dutch-American Relations" conference, Vrije Universiteit, 
Amsterdam:15-16 October 2009.

58 It is estimated that one third of sailors on Middelburgsche Commercie Compagnie (MCC) ships were foreigners, and a large number of WIC sailors, as well. See Postma, The Dutch in the Atlantic Slave Trade, 153. Some 64 per cent of all WIC soldiers recruited for Dutch Brazil were not born in the Netherlands but elsewhere, particularly in the German provinces. See Miranda, Gente de Guerra. Later in the history of the WIC, approximately half of all WIC soldiers were non-Dutch. See Klooster, "Other Netherlands beyond the Sea," 173. The WIC was dependent on non-Dutch personnel not only as soldiers and sailors, but also in the higher ranks of the organisation itself. For example, 39\% of WIC employees on the Gold Coast were foreigners, mostly from Germany, Scandinavia, and the southern Netherlands in the seventeenth century. See Den Heijer, "Een dienaar van vele heren," 162-80.

59 The ships of all nations engaged in the regional Caribbean trade (including North American ships) often had mixed crews. Black and colored sailors, both free and slave, were a very common sight in Caribbean ports. See, for example, Bolster, Black Jacks; Scott, The Common Wind; and Jordaan, Slavernij en vrijheid op Curaçao. Thanks to Han Jordaan for bringing this to our attention.

60 See the work of Kruijtzer, Xenophobia in Seventeenth-Century India.

61 Emmer and Klooster, "The Dutch Atlantic," 49. For the heterogeneous nature of the British Atlantic, see Devine, Scotland's Empire, 1600-1815; O'Neill and Lloyd, eds., The Black and Green Atlantic; Fortune, Merchants and Jews. For the Dutch, see the already cited work of Hatfield and Schnurmann, as well as Klooster, "AngloDutch Trade in the Seventeenth Century: An Atlantic Partnership?" 261-84.

62 Herzog, Defining Nations.

63 The shortage of settlers also led to schemes to send the destitute to populate these lands, schemes that the Ashkenazim and Sephardim, among others, eagerly supported in order to rid themselves of a large drain on their communal coffers. See, for instance, Goslinga, The Dutch in the Caribbean and on the Wild Coast, 40; Rees, Geschiedenis der Staathuishoudkunde in Nederland tot het einde der achttiende eeuw, 76. For the specific history of Jewish schemes to send away their poor, see Cohen, Jews in a
Another Environment.

64 Klooster, "Other Netherlands beyond the Sea," 177.

65 Bosch, Reize in West-Indië, vol. I.220, 226, 228; Knight and Prime, eds., St. Thomas 1803, Crossroads of the Diaspora.

66 Schalkwijk, The Colonial State in the Caribbean.

67 Gabaccia, "A Long Atlantic in a Wider World," 1-27; 8.

68 Games, "Atlantic Ocean”. 1 Mar. 2012 <http://www.encyclopedia.com>.

69 Gabaccia, "A Long Atlantic in a Wider World."

70 Bailyn, Atlantic History: Concept and Contours, 62-63.

71 Ibid., 62-81 and Elliott, Empires of the Atlantic, 1-114.

72 Elliott, Empires of the Atlantic, 1-114.

73 Bailyn, Atlantic History, 62-81.

74 Ibid., 81-101 and Elliott, Empires of the Atlantic, 115-251.

75 De Vries, "The Dutch Atlantic Economies."

76 On the history of Atlantic history, see Andrews, The Colonial Period of American History and Haring, The Spanish Empire in America; Bailyn, "The Idea of Atlantic History," 19-44; O'Reilly, "Genealogies of Atlantic History," 66-84; and Games, "Atlantic History: Definitions, Challenges, and Opportunities," 741-57, 743.

77 Curtin, The Atlantic Slave Trade: A Census; Games, "Atlantic History: Definitions, Challenges, and Opportunities," 743.

78 Games, "Atlantic History: Definitions, Challenges, and Opportunities," 744.

79 O'Reilly, "Genealogies of Atlantic History," 69.

80 Ibid.

81 Hancock, "The British Atlantic World," 107 26, 110.

82 Putnam, "To Study the Fragments/Whole," 615-30, 620.

83 Armitage and Braddick, eds., The British Atlantic World, 1500-1800 is a prime example of this. Armitage's oft-quoted essay in this volume in which he conceptualises three different types of Atlantic history is particularly innovative for understanding all endeavors in the Atlantic, not just the British. See Armitage, "Three Concepts of Atlantic History," 11-27.

84 Games, "Atlantic History: Definitions, Challenges, and Opportunities," 744.

85 Eltis, "Atlantic History in Global Perspective," 141-61, 141

86 Elliot, "Afterword, Atlantic History: A Circumnavigation," 233-49, 236.

87 Coclanis, "Atlantic World or Atlantic/World?" 
725-42; Emmer, "The Myth of Early Globalization: The Atlantic Economy, 1500-1800," 37-47; Coclanis, "Drang Nach Osten," 169-82; Games, "Beyond the Atlantic," 675-92; Wood, "From Atlantic History to a Continental Approach," 279-98; Greene, "Hemispheric History and Atlantic History," 299-316; Canny, "Atlantic History and Global History," 317-36; and Coclanis, "Beyond Atlantic History," 337-56.

88 Morgan and Greene, "Introduction: The Present State of Atlantic History," 3-33, 10.

89 Emmer and Klooster, "The Dutch Atlantic." De Vries and Schmidt, at least implicitly, agree with this perspective. See Schmidt, "The Dutch Atlantic: From Provincialism to Globalism," 163-90, and De Vries, "The Dutch Atlantic Economies," 21.

90 Postma and Enthoven, eds. Riches from Atlantic Commerce.

91 Schmidt, Innocence Abroad; "The Dutch Atlantic: From Provincialism to Globalism;" and Going Dutch.

92 De Vries, "The Dutch Atlantic Economies," 21.

93 Of course, "expansion without empire" comes from Emmer and Klooster, "The Dutch Atlantic, 1600-1800: Expansion without Empire." Here we paraphrase CanizaresEsguerra, "AHR Forum: Entangled Histories: Borderland Historiographies in New Clothes?" < http://www.historycooperative. org/journals/ahr/112.3/canizaresesguerra. html > (9 Mar. 2012).

94 Armitage, "Three Concepts of Atlantic History." Armitage identified three types of Atlantic history as a way to combine all the emerging strands of Atlantic history into a more coherent and overarching theoretical whole. Coclanis engaged with Armitage's tripartite typology and, in response, proposed a fourth type of Atlantic history-conjunctohistory, which studies in the relationship between the Atlantic and the rest of the world. See Coclanis, "Atlantic World or Atlantic/ World?" 725-42; 739.

95 To list only a few, see Costigan, Through Cracks in the Wall; Mandelblatt, "A Transatlantic Commodity," 18-47; and Norton, Sacred Gifts, Profane Pleasures.

96 Armitage, "Three Concepts of Atlantic History," 22.

97 Chaunu and Chaunu, Séville et l'Atlantique.

98 For instance, obvious Dutch nodal points would be Amsterdam, Rotterdam and Middelburg/Vlissingen in the Netherlands; Elmina, in present-day Ghana; and in the Caribbean, Paramaribo (Suriname), Willemstad (Curaçao) and St. Eustatius. There could, of course, be many other Dutch nodal points in the Atlantic. Although they are outside the chronology we have chosen for building our framework, Dutch Brazil and New Netherland were crucial nodal points for the Dutch in the Atlantic.

99 Price, "Economic Function and the Growth of American Port Towns," 121-86.

100 Liss and Knight, "Introduction," 1-12; 10.

101 Ibid., 6-7.

102 Hancock, "The Trouble with Networks," 467-91, 467.

103 Ibid., 467.

104 Games, "Atlantic History: Definitions, Challenges, and Opportunities," 744.

105 Canizares-Esguerra, "AHR Forum: Entangled Histories: Borderland Historiographies in New Clothes?"

106 Schnurmann, "Atlantic Trade and American Identities," 179-98.

107 To paraphrase Armitage, "Three Concepts of Atlantic History," 23.

108 See Hatfield, Atlantic Virginia, 227.

109 Coclanis, "Beyond Atlantic History," 33756. 